\title{
Dynamics of Plasmatic Levels of Pro- and Anti-Inflammatory Cytokines in HIV-Infected Individuals with M. tuberculosis Co-Infection
}

\author{
Marina Nosik ${ }^{1, *(\mathbb{D})}$, Konstantin Ryzhov ${ }^{1}$, Irina Rymanova ${ }^{2}$, Alexandr Sobkin ${ }^{2}$, Alexey Kravtchenko ${ }^{3}$, \\ Ulyana Kuimova $^{3}$, Vadim Pokrovsky ${ }^{3}$, Vitaly Zverev ${ }^{1}$ and Oxana Svitich ${ }^{1}$ \\ 1 I.I. Mechnikov Institute of Vaccine and Sera, 105064 Moscow, Russia; rkazaw@yahoo.com (K.R.); \\ vitalyzverev@outlook.com (V.Z.); svitichoa@yandex.ru (O.S.) \\ 2 G.A. Zaharyan Moscow Tuberculosis Clinic, Department for Treatment of TB Patients with HIV Infection, \\ 125466 Moscow, Russia; rimanov.81@mail.ru (I.R.); alexandr@sobkin.net (A.S.) \\ 3 Central Research Institute of Epidemiology, 111123 Moscow, Russia; alexey-kravtchenko@yandex.ru (A.K.); \\ ulyanakuimova@gmail.com (U.K.); pokrovsky.vad@yandex.ru (V.P.) \\ * Correspondence: mnossik@yandex.ru
}

check for updates

Citation: Nosik, M.; Ryzhov, K.; Rymanova, I.; Sobkin, A.; Kravtchenko, A.; Kuimova, U.; Pokrovsky, V.; Zverev, V.; Svitich, O. Dynamics of Plasmatic Levels of Proand Anti-Inflammatory Cytokines in HIV-Infected Individuals with M. tuberculosis Co-Infection. Microorganisms 2021, 9, 2291. https://doi.org/10.3390/ microorganisms 9112291

Academic Editors: Pavel Bostik and Shubhada Bopegamage

Received: 5 October 2021

Accepted: 2 November 2021

Published: 4 November 2021

Publisher's Note: MDPI stays neutral with regard to jurisdictional claims in published maps and institutional affiliations.

Copyright: (c) 2021 by the authors. Licensee MDPI, Basel, Switzerland. This article is an open access article distributed under the terms and conditions of the Creative Commons Attribution (CC BY) license (https:// creativecommons.org/licenses/by/ $4.0 /)$.

\begin{abstract}
Tuberculosis (TB) and HIV have profound effects on the immune system, which can lead to the activation of viral replication and negatively regulate the activation of $\mathrm{T}$ cells. Dysregulation in the production of cytokines necessary to fight HIV and M. tuberculosis may ultimately affect the results of the treatment and be important in the pathogenesis of HIV infection and TB. This work presents the results of a study of the expression of pro- and anti-inflammatory cytokines (IFN- $\gamma$, TNF- $\alpha$, IL-2, IL-4, IL-6, IL-10, IL-1RA) in drug-naïve patients with dual infection of HIV / TB at the late stages of HIV-infection, with newly diagnosed HIV and TB, and previously untreated HIV in the process of receiving antiretroviral (ART) and TB treatment vs. a cohort of patients with HIV monoinfection and TB monoinfection. The study revealed that during a double HIV/TB infection, both Th1 and Th2 immune responses are suppressed, and a prolonged dysregulation of the immune response and an increased severity of the disease in pulmonary/extrapulmonary tuberculosis is observed in HIV/TB co-infection. Moreover, it was revealed that a double HIV/TB infection is characterized by delayed and incomplete recovery of immune activity. High levels of IL-6 were detected in patients with HIV/TB co-infection before initiation of dual therapy (2.1-fold increase vs. HIV), which persisted even after 6 months of treatment (8.96-fold increase vs. HIV), unlike other cytokines. The persistent enhanced expression of IL-6 in patients with dual HIV/TB co-infection allows the consideration of it as a potential marker of early detection of $\mathrm{M}$. tuberculosis infection in HIV-infected individuals. The results of multivariate regression analysis showed a statistical trend towards an increase in the incidence of IRIS in patients with high IL-1Ra levels (in the range of 1550-2500 pg/mL): OR = 4.3 (95\%CI 3.7-14.12, $p=0.53$ ), which also allows IL-1Ra to be considered as a potential predictive biomarker of the development of TB-IRIS and treatment outcomes.
\end{abstract}

Keywords: HIV; tuberculosis; HIV/TB co-infection; cytokine profile; ART; immune reconstitution inflammatory syndrome

\section{Introduction}

Currently, it is well known that both HIV and tuberculosis (TB) have a profound effect on the immune system and are characterized by a dysregulation of the normal balance of cytokines and the functioning of the cytokine network. In the pathogenesis of these infections, the imbalance of cytokines produced by Th1 and Th2 lymphocytes and macrophages occupies a central place, affecting the strength of the immune system's response to specific pathogens [1-3]. The imbalance of cytokine secretion in HIV infection affects the function of the immune system and the course of the disease, increasing or suppressing 
viral replication $[4,5]$. Numerous data indicate that, despite effective antiretroviral therapy (ART), there is evidence of persistent viral production and persistent immune activation in HIV-infected individuals [6-8]. It has been shown that persistent immune activation during viral load suppression correlates with a high risk of developing concomitant diseases not related to AIDS, including metabolic syndrome [9-12], cardiovascular diseases [9,13-15], neurocognitive disorders [16-19], and malignant neoplasms [20-23] and is also directly associated with increased mortality [24,25].

Immunosuppression caused by HIV- 1 can also be aggravated by persistent $M t b$ (M. tuberculosis) infection. The first line of defense against $M t b$ is alveolar macrophages, which are capable of suppressing bacterial growth through phagocytosis, as well as participating in a wide range of reactions of cellular anti-tuberculosis immunity [26]. However, if $M t b$ manages to disrupt the autophagy process via various mechanisms, then macrophages become a reservoir for slow $M t b$ replication and then a reservoir for the persistent infection inside the phagosome in the latent form of TB $[27,28]$. As a result, immune activation is observed both in the active form of TB and in the latent form [29].

It is generally known that cytokines are significant parts of the immune response. Different cytokines have biologically overlapping functions and can regulate the production of other cytokines [30-32]. Therefore, the analysis of cytokines expressed during a double HIV / TB infection while patients receive ART may be important for predicting the course of the disease and the success of the treatment. The determination of plasma cytokine concentration levels can provide clinicians with prognostic markers for monitoring the damage/recovery of the immune system. At present, the production of various cytokines in HIV/TB co-infection is still insufficiently studied. There are few works devoted to the problem of studying the cytokine profile in HIV patients in the process of receiving ART. There is almost no work on the study of the cytokine status in patients with a combined $\mathrm{HIV} / \mathrm{TB}$ infection before and in the process of receiving dual therapy-antiretroviral and anti-tuberculosis. However, for understanding the pathogenesis of a combined infection and effective treatment, it is vital to accurately know how deeply disturbed the production of various cytokines in patients with HIV/TB. The goal of this work was to study the expression of a number of pro-inflammatory and anti-inflammatory cytokines in patients with double HIV/TB infection, newly diagnosed with HIV and TB, and previously untreated HIV before and during the process of receiving antiretroviral/anti-tuberculosis therapy and to identify possible potential predictive markers that allow clinicians to foresee the development of the disease and evaluate the effectiveness of therapy.

\section{Materials and Methods}

\subsection{Study Group}

The subjects were recruited from three different population pools at two large medical centers: the G.A. Zaharyan Moscow Tuberculosis Clinic and Central Research Institute of Epidemiology: patients with dual HIV/TB infection, HIV-positive patients, patients with TB, and healthy controls. Patients with HIV/TB were naïve for ART and anti-tuberculosis therapy, HIV-positive patients were naïve for ART, and TB patients were naïve for antituberculosis therapy. TB diagnoses were based on clinical symptoms, sputum microscopy and radiological analyses. The patients were diagnosed as HIV-seropositive by ELISA and confirmed by Western blot. Healthy controls from the general population that were seronegative for HIV and without any history of TB or exposure to the disease within the past 6 months were recruited for the study.

All patients with HIV-monoinfection were newly diagnosed with HIV. In a cohort of patients with $\mathrm{HIV} / \mathrm{TB}, 40.3 \%$ of the patients were aware of their HIV-positive status before admission to the hospital, were drug-naïve and were newly diagnosed with TB. Moreover, $59.7 \%$ of the patients with HIV / TB were newly diagnosed with HIV and TB. All patients with TB alone were newly diagnosed with TB. The ART for patients with HIV-monoinfection was started immediately after admission to the hospital, as well as anti-tuberculosis treatment (ATT) for patients with TB-monoinfection. As for HIV/TB 
patients, ATT was started after admission to the hospital and ART was started within 2-3 weeks after the initiation of TB therapy. The ART regimen was: 2 NRTIs + 1 NNRTI $(74.5 \%)$ and 2 NRTIs +1 IP $(25.5 \%)$. For the treatment of TB, first-line drugs were used (isoniazid, rifampicin, streptomycin, and ethambutol). No differences in the expression of cytokines were observed for diverse therapy regimens.

Patients who developed inflammatory immune recovery syndrome (IRIS) after starting the therapy were excluded from the study, as these patients represented a special group characterized by an atypical manifestation of clinical and immunological indicators. On average, the percentage of cases of IRIS in HIV/TB co-infection is relatively low, so it seemed more important to study the expression of cytokines in a group of HIV / TB patients who did not develop IRIS and who represent the majority of patients in percentage terms. The only exception was made when quantifying the levels of IL-1RA given the extreme importance that this cytokine plays in the development and course of TB, in particular in restraining and preventing the spread of infection by the formation of granulomas. In patients who developed IRIS, ART was temporarily interrupted, and the period of ATT without antiretroviral drugs was prolonged up to 12-15 weeks. At the end of this period, antiretroviral therapy was again resumed. The patients were monitored for up to 6 months. Blood samples were collected prior to the commencement of ART/anti-tuberculosis therapy and 30,45-75, and 180 days after the initiation of treatment. Plasma was separated from the whole blood samples and stored at $-80^{\circ} \mathrm{C}$ until further analysis.

\subsection{Ethical Aspects}

All patients were over 18 years old and gave written informed consent for participation in the study. According to the General Data Protection Regulation (GDPR) requirements, all participants were de-identified and anonymized by assigning them unique codes expressed as an identifier. All clinical samples, data and study results were stored in an anonymized form. The study was conducted according to the guidelines of the Declaration of Helsinki and approved by the Biomedical Ethics Committee of the I.I. Mechnikov Institute of Vaccines and Sera, Moscow, Russia (protocol \#1/01/17/2018).

\subsection{Sputum Microscopy and Culture}

Sputum samples were stained for acid-fast bacilli and were graded by light microscopy. Cultures were examined weekly until positive for visible colonies or for a maximum of 8 weeks.

\subsection{CD4+ T-CELL Count}

The CD4+ T-CELL count was carried out according to a standard procedure. The CD4+ T cell counting was performed by two-color flow cytometry using phycoerythrin-labeled anti-CD4 antibodies (FACSort, Becton Dickinson, Franklin Lakes, NJ, USA) according to the manufacturer's instructions. The whole blood sample with anticoagulant was incubated with the fluorescent antibodies, and then the CD4+ cell number was determined by flow cytometry using Fluorescent Activated Cell Sorter BD FACSCount TM system (Becton Dickinson).

\subsection{Cytokine Quantitation}

All cytokines were measured before the initiation of therapy in all studied groups. In patients with HIV alone-before initiation of ART; in patients with TB alone-before initiation of ATT. The cytokines in the cohort of patients with HIV/TB were measured before the start of dual therapy-antiretroviral, as well as anti-tubercular treatment. Afterwards the cytokines were measured at 30, 60, 75-90 and 150-180 days after initiation of treatment. Plasma levels of the cytokines IL-1Ra, IL-2, IL-4, IL-6, IL-10, IFN- $\gamma$, and TNF- $\alpha$ were measured using ELISA EIA-BEST Kit (Vector-Best, Moscow, Russia, RF). Plasma was isolated according to the standard procedure. The whole blood was collected in a vacutainer with EDTA and centrifuged at $1000 \mathrm{rmp}$ for 15-20 min. Then the plasma was aliquoted and 
stored at $-80^{\circ} \mathrm{C}$ until further analysis. The cytokine concentrations were determined using a standard curve obtained with the standards provided by the manufacturer with each kit (sensitivity $0-5 \mathrm{pg} / \mathrm{mL}$ ), and the results were expressed as $\mathrm{pg} / \mathrm{mL}$.

\subsection{TB-IRIS Definition}

Paradoxical TB-IRIS was defined as the presence of at least one major or two minor TBIRIS clinical criteria according to the International Network for the Study of HIV-Associated IRIS case definition (INSHI) [33]. Major TB-IRIS criteria were new or worsening (1) lymph nodes, cold abscesses, or other focal tissue involvement; (2) radiologic features of TB; (3) central nervous system TB; or (4) serositis (pleural effusion, (pleural effusion, ascites, or pericardial effusion). Minor TB-IRIS criteria were new or worsening: (1) constitutional symptoms (fever, night sweats, or weight loss), (2) respiratory symptoms (cough, dyspnea), and (3) abdominal pain accompanied by peritonitis, hepatomegaly, splenomegaly, or abdominal adenopathy [33]. Lymph node TB-IRIS was defined by enlarged peripheral lymph nodes on clinical examination, enlarged thoracic nodes on a chest radiograph, or enlarged abdominal nodes on an ultrasound or CT scan. Abdominal TB-IRIS was defined by abdominal symptoms attributed to TB-IRIS.

\subsection{Statistical Analysis}

The nonparametric Mann-Whitney test was performed to check for the significant differences. A $p$-value $<0.05$ was considered significant. Multivariate regression analysis was employed in order to evaluate the incidence of TB-IRIS in patients with HIV/TB co-infection. Data analysis was performed using IBM SPSS Statistics 17.0.

\section{Results}

A total of 356 people participated in the study: 116 patients with HIV/TB co-infection (11 patients were subsequently excluded from the study due to non-compliance with the treatment regimen and 16 patients who developed IRIS), 80 patients with HIV monoinfection, 78 patients with TB monoinfection, and 82 healthy controls. Baseline demographic and clinical characteristics of the patients are presented in Table 1. The groups did not differ significantly in demographic indicators. Men predominated in all groups, and the median age was 37.8 years for men and 39.7 years for women. The median CD4+ cell count in the group of patients with double infection was 114 cells $/ \mathrm{mm}^{3}$, and the viral load was $6.8 \log _{10}$ copies $/ \mathrm{mL}$. Patients with severe immunosuppression prevailed in this group (71.9\%). In patients with HIV alone, the viral load was approximately the same as in the HIV / TB co-infection group $\left(6.2 \log _{10}\right.$ copies $\left./ \mathrm{mL}\right)$, but the percentage of patients with severe immunosuppression was lower (40.3\%). Disseminated tuberculosis prevailed among patients with HIV/TB (46.1\%), and infiltrative tuberculosis prevailed among patients with TB only (67.9\%). There were no fatal outcomes among the patients recruited in the study, and in the process of treatment in the study group, there were no patients who developed MDR- or XDR-TB.

\subsection{Expression of Cytokines before ART}

The group of patients with combined HIV/TB infection before the start of dual therapy (anti-tubercular and antiretroviral) had reduced expression of the Th1 cytokines interferon$\gamma($ IFN- $\gamma$ ), tumor necrosis factor- $\alpha$ (TNF- $\alpha$ ), and interleukin-2 (IL-2) compared with the group of patients with HIV monoinfection and TB monoinfection (Figure 1). There was a 1.7-fold decrease of INF- $\gamma$ production in patients with HIV/TB co-infection compared to the group of patients with HIV monoinfection and a 2.3-fold decrease in comparison with the group of patients with TB monoinfection $(p=0.002$ and $p=0.002$, respectively). TNF- $\alpha$ secretion was reduced in patients with HIV/TB against patients with HIV alone by 1.6 times $(p=0.002)$ and against patients with TB only by 2.1 times $(p=0.002)$. 
Table 1. Baseline demographic and clinical characteristics of the study population.

\begin{tabular}{|c|c|c|c|c|}
\hline Characteristics & $\begin{array}{l}\text { HIV/TB } \\
(n=89)\end{array}$ & $\begin{array}{c}\text { HIV } \\
(n=80)\end{array}$ & $\begin{array}{c}\text { TB } \\
(n=78)\end{array}$ & $\begin{array}{l}\text { Healthy } \\
\text { Controls } \\
(n=82)\end{array}$ \\
\hline \multicolumn{5}{|l|}{ Gender, $(n / \%)$ : } \\
\hline Male & $58(65.2)$ & 49 (61.3) & $53(67.9)$ & $56(68.2)$ \\
\hline Female & $31(34.8)$ & 31 (38.7) & $25(32.1)$ & $26(31.7)$ \\
\hline \multicolumn{5}{|l|}{ Age (years), IQR: } \\
\hline Male & $37.9(24-72)$ & $37.5(23-68)$ & $36.9(28-68)$ & $34.9(22-48)$ \\
\hline Female & $38.6(22-72)$ & $42.3(22-70)$ & $44.5(32-71)$ & $37.2(24-45)$ \\
\hline \multicolumn{5}{|l|}{ TB forms, $(n / \%)$ : } \\
\hline Disseminated & $41(46.1)$ & & $17(21.8)$ & \\
\hline Infiltrative & $36(40.4)$ & & $53(67.9)$ & \\
\hline $\begin{array}{c}\text { TB of intrathoracic } \\
\text { lymph nodes }\end{array}$ & $9(10.1)$ & & $7(9.0)$ & \\
\hline Others & $3(3.4)$ & 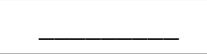 & $1(1.3)$ & 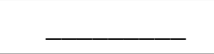 \\
\hline \multicolumn{5}{|l|}{$\begin{array}{c}\text { CD4+ count } \\
\left(\text { cells } / \mathrm{mm}^{3}\right), \\
\%, \mathrm{IQR}:\end{array}$} \\
\hline$<200$ & $\begin{array}{c}71.9 \% / 57 \\
(6-157)\end{array}$ & $110(44-189)$ & & \\
\hline$<350$ & $\begin{array}{l}19.1 \% / 215 \\
(203-310)\end{array}$ & $272(222-342)$ & & \\
\hline$>350$ & $\begin{array}{c}9 \% / 352 \\
(352-380)\end{array}$ & $553(383-711)$ & $487(379-520)$ & $978(800-1200)$ \\
\hline $\begin{array}{l}\text { Viral load (log } 10 \\
\text { copies/mL), IQR }\end{array}$ & $6.8(1.9-7.1)$ & $6.2(1.5-6.5)$ & & - \\
\hline
\end{tabular}

The concentration of plasma IL-2 in patients with double infection was reduced by 3.3 times compared to the group of patients with HIV monoinfection $(p=0.001)$ and by 4.2 times compared to the group with TB monoinfection $(p=0.001)$. Altogether, the production of IFN- $\gamma$, TNF- $\alpha$, and IL-2 in patients with HIV /TB, HIV, and TB was higher compared with the group of healthy controls $(p<0.001 ; p<0.001 ; p<0.001$, respectively).

Furthermore, in patients with HIV/TB, a reduced expression of Th2 class cytokines was detected before the initiation of dual therapy compared to the groups of patients with HIV monoinfection and TB monoinfection (Figure 1). Thus, the concentration of interleukin-4 (IL-4) was reduced in the group of patients with HIV/TB compared with the group of patients with HIV by 2.7 times $(p=0.002)$ and by 4 times with the group of patients with TB $(p=0.002)$. The level of interleukin-10 (IL-10) production in the HIV/TB group was reduced 15.6 times compared to the HIV group $(p=0.001)$ and 21.6 times $(p=0.001)$ compared to the HIV group. The level of IL-10 in patients with HIV/TB was even lower than in the control group $(p<0.001)$.

A different pattern was observed in the expression of the cytokines interleukin-6 (IL-6) and interleukin-1 receptor antagonist (IL-1Ra) (Figure 1). Prior to the start of therapy, IL-6 secretion in patients with HIV/TB was increased by 2.1 times compared to the group of patients with HIV alone $(p=0.002)$ and was actually on the same level as in the group of patients with TB monoinfection ( $p=0.003)$. IL-1Ra secretion was also significantly increased compared with patients with HIV monoinfection by 4 times $(p=0.002)$ and compared with patients with TB monoinfection by 3.6 times $(p=0.002)$. 


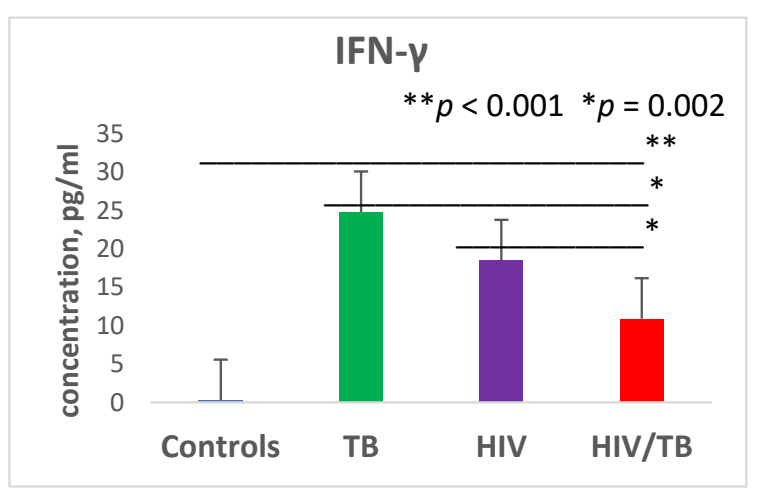

(A)

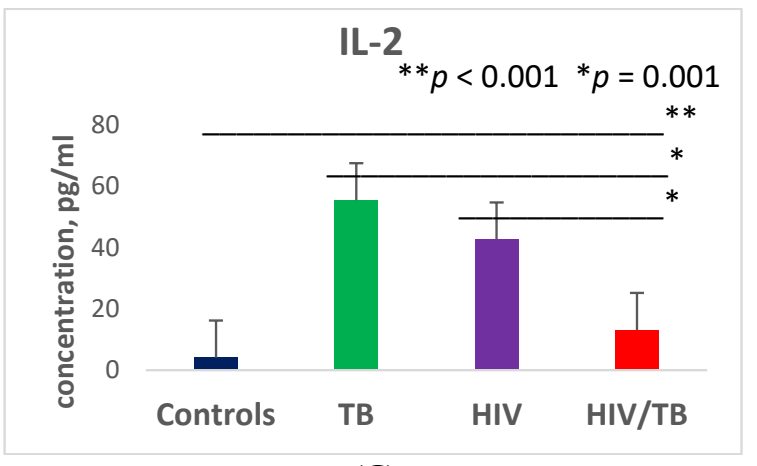

(C)

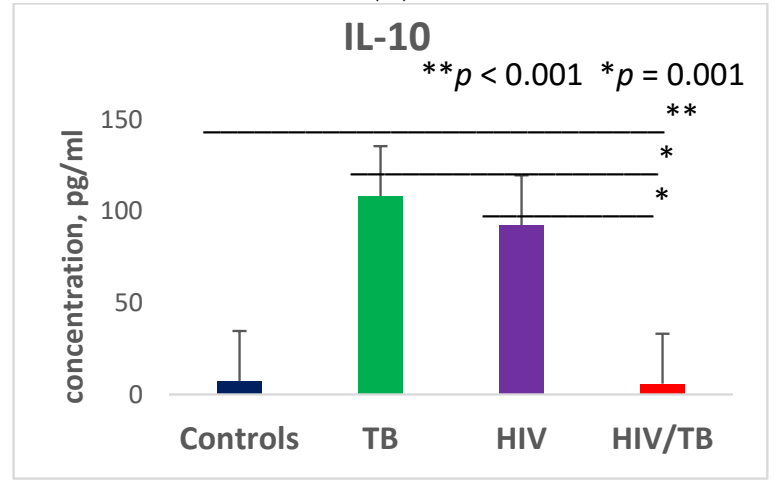

(E)

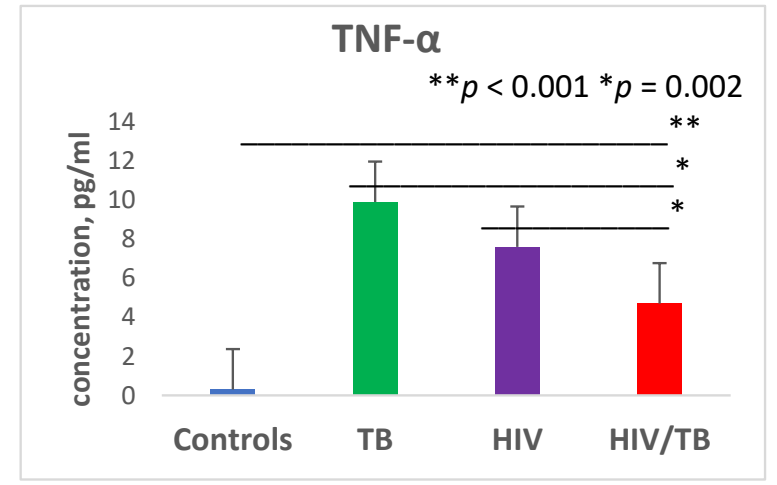

(B)

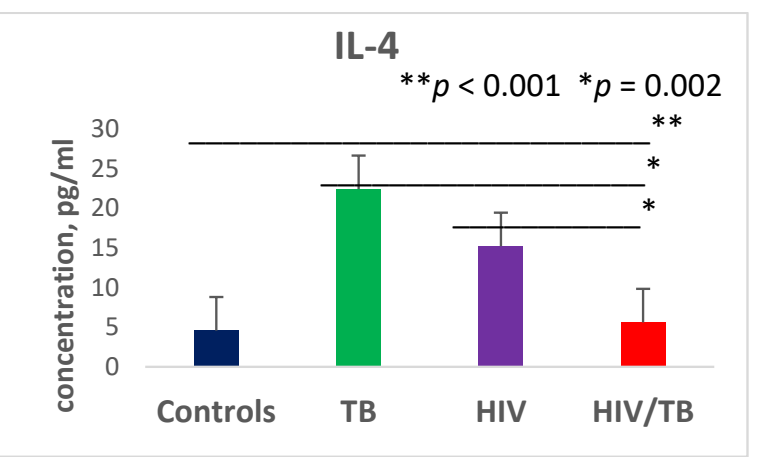

(D)

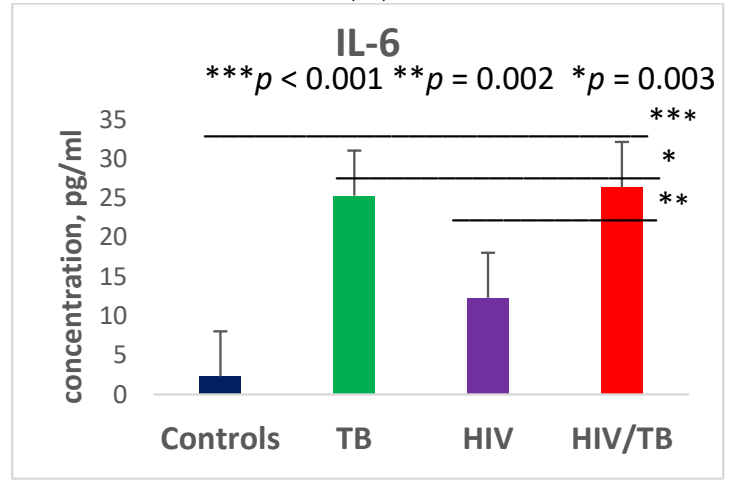

(F)

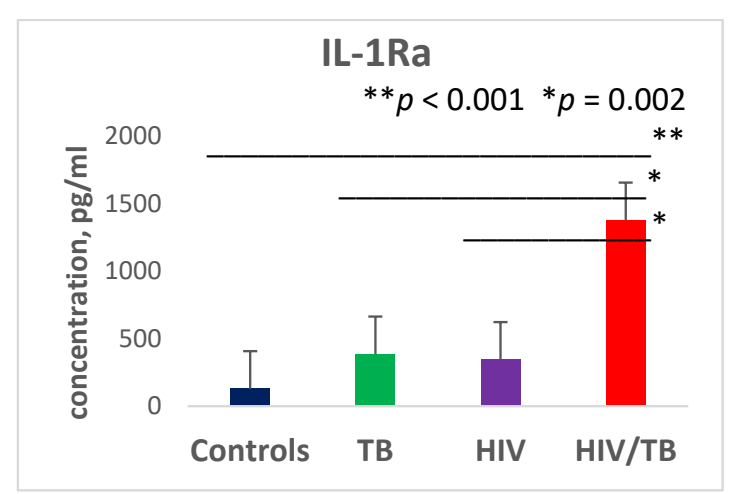

(G)

Figure 1. Plasma levels of different cytokines in patients with dual HIV/TB infection, HIV monoinfection, TB monoinfection, and healthy controls before therapy: interferon- $\gamma(\mathrm{IFN}-\gamma)(\mathbf{A})$, tumor necrosis factor- $\alpha$ (TNF- $\alpha)$ (B), interleukin-2 (IL-2) (C), interleukin-4 (IL-4) (D), interleukin-6 (IL-6) (E), interleukin-10 (IL-10) (F), and interleukin-1 receptor antagonist (IL-1RA) (G). Bars represent standard deviation. 
There was no correlation between the level of cytokine expression, viral load, and the number of CD4 cells.

\subsection{Expression of Cytokines in the Process of Treatment}

If patients with HIV / TB showed a significant decrease in the secretion of most Th1 and Th2 class cytokines before the start of therapy (antiretroviral and anti-tubercular), the observation of this group of patients in the process of receiving therapy showed that, in general, in patients with HIV / TB co-infection, the levels of most pro- and anti-inflammatory cytokines in the blood plasma were significantly higher during the 180 days of treatment than in the control group and in the group of patients with HIV only or only with TB (Figures 2 and 3 ).

At the same time, in patients with HIV monoinfection and TB monoinfection, a level of cytokine secretion comparable to similar indicators in the group of healthy controls was already observed, on average, at 30-60 days of treatment. Thus, in the group of patients with TB alone, a level of expression of IL- 2 and TNF- $\alpha$ comparable to similar indicators in the control group was reached on the 30th day after the start of therapy, and in the HIV group, this was achieved on the 60th day after the initiation of therapy. In the group of patients with combined HIV/TB infection, on the 180th day of therapy, the concentration of IL-2 increased by an average of 3.3 times compared to the other three groups $(p=0.007)$, and the concentration of TNF- $\alpha$ exceeded 15.7 times the level of the same indicator in the control group, 3.9 times in the group with TB alone, and 1.6 times in the group of patients with HIV monoinfection ( $p=0.009 ; p=0.02$ and $p=0.02$, respectively). The levels of expression of IL-4 and IL-10 comparable to those for similar indicators in the control group in patients with TB were achieved after 30 days of therapy, while in patients with HIV, this was achieved after 75 days of therapy, and in the HIV / TB group, this was achieved only on the 150th day of therapy. For IFN- $\gamma$ and IL-1Ra, a secretion level comparable to similar indicators in the control group was reached after 180 days of therapy.

The exception was the cytokine IL-6. On the 180th day after therapy, the level of IL-6 expression in the HIV/TB group was 11.3 times higher compared to the control group and the TB group, and 8.96 times higher compared to the group of patients with HIV monoinfection ( $p=0.001 ; p=0.001 ; p=0.001$, respectively), actually remaining at the same level as before the initiation of therapy.

Additionally, before the start of ART, in the process of receiving therapy, neither in patients with HIV/TB nor in patients with HIV alone was there a significant correlation between the level of cytokine expression, viral load, and the number of CD4 cells.

\subsection{Expression of Cytokines Depending on the CD4+ Cell Count}

In order to identify a possible correlation of the level of cytokine expression with the number of CD4+ cells, the secretion of some pro- and anti-inflammatory cytokines was studied in a group of patients with CD4 $+<200$ and CD4+ $>200$ cells $/ \mathrm{mm}^{3}$ (Figure 4).

In a comparative study of the level of production of IL-2, IL-4, and IL-6 between the two groups, practically no difference was found, both before therapy and on the 180th day of receiving therapy. At the same time, an increase in the expression of IL-6 in both groups was detected by 1.7 times on the 60th day after the start of therapy $(p=0.003)$. However, on the 180th day of therapy, the secretion of IL-6 decreased and remained at the same level as before therapy.

Lower levels of TNF- $\alpha$ and Il-10 production were observed in the group of patients with CD4+ $>200$ cells $/ \mathrm{mm}^{3}$ compared to the group of CD4+<200 cells $/ \mathrm{mm}^{3}$ : for TNF- $\alpha$, the expression level was 1.6 times below the other group $(p=0.03)$, and for IL-10, the value was 2.2 times below the other group $(p=0.009)$. 


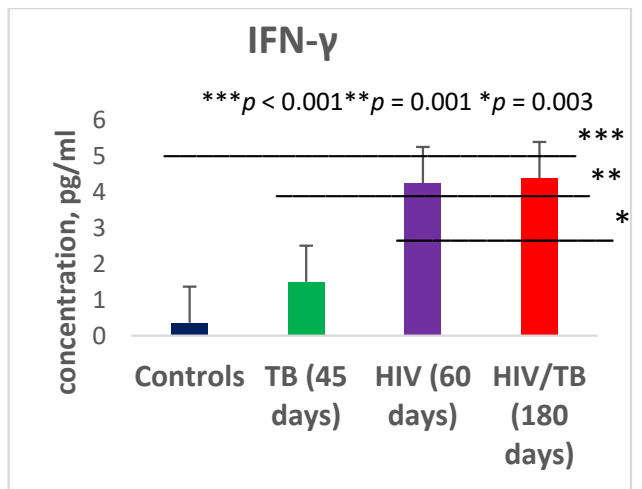

(A)

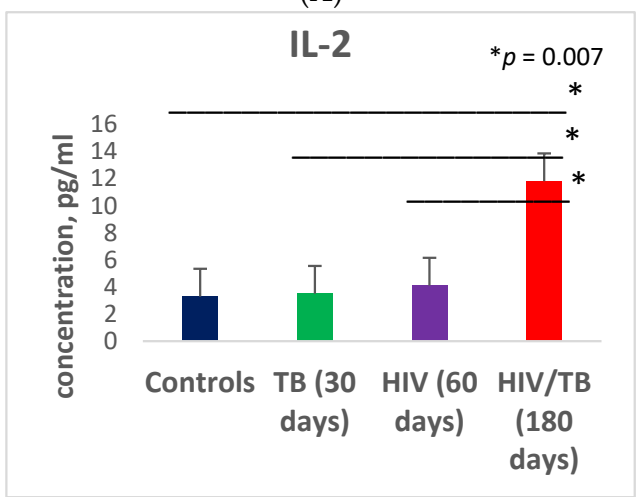

(C)

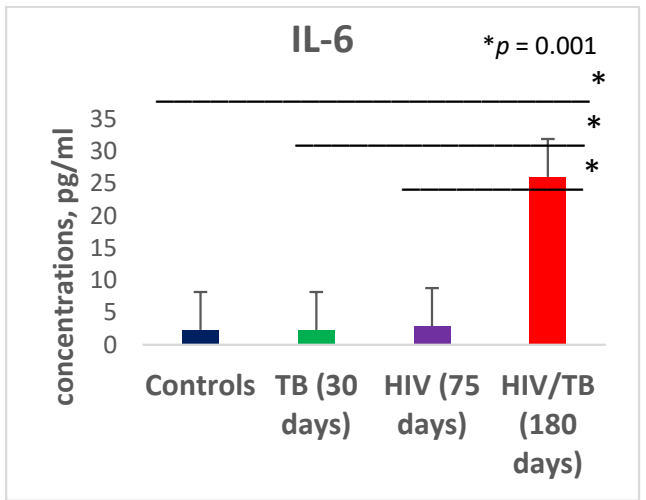

(E)

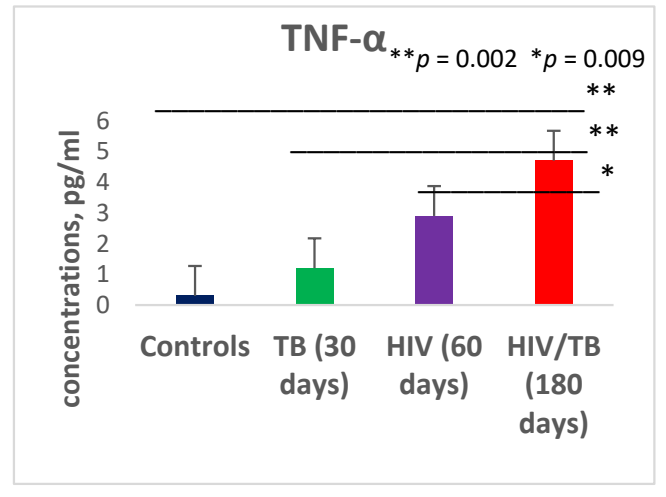

(B)

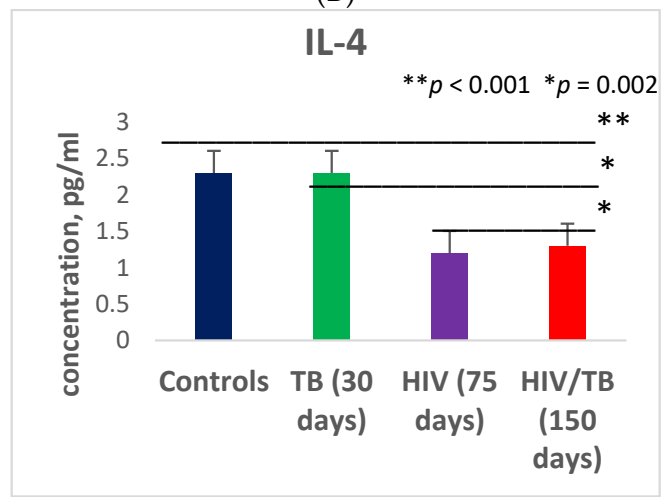

(D)

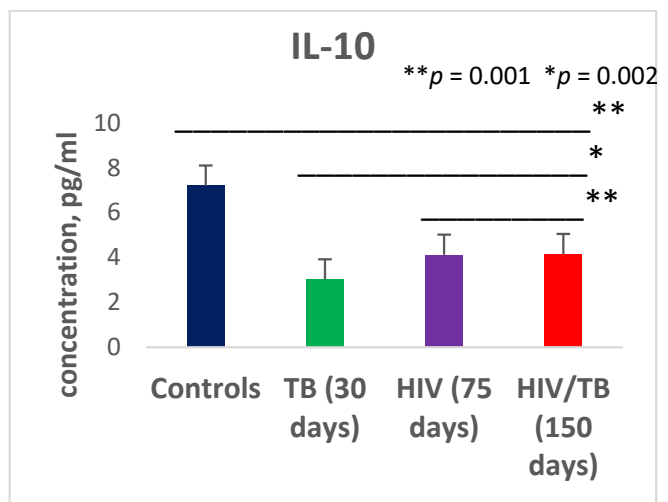

(F)

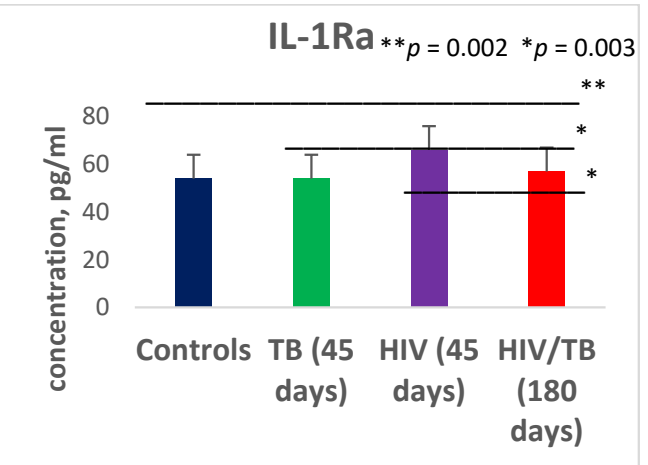

(G)

Figure 2. Plasma levels of different cytokines in patients with dual HIV/TB infection, HIV monoinfection, TB monoinfection, and healthy donors after dual therapy: interferon- $\gamma$ (IFN- $\gamma)(\mathbf{A})$, tumor necrosis factor- $\alpha$ (TNF- $\alpha)$ (B), interleukin-2 (IL-2) (C), interleukin-4 (IL-4) (D), interleukin-6 (IL-6) (E), interleukin-10 (IL-10) (F), and interleukin-1 receptor antagonist (IL-1RA) (G). Bars represent standard deviation. 


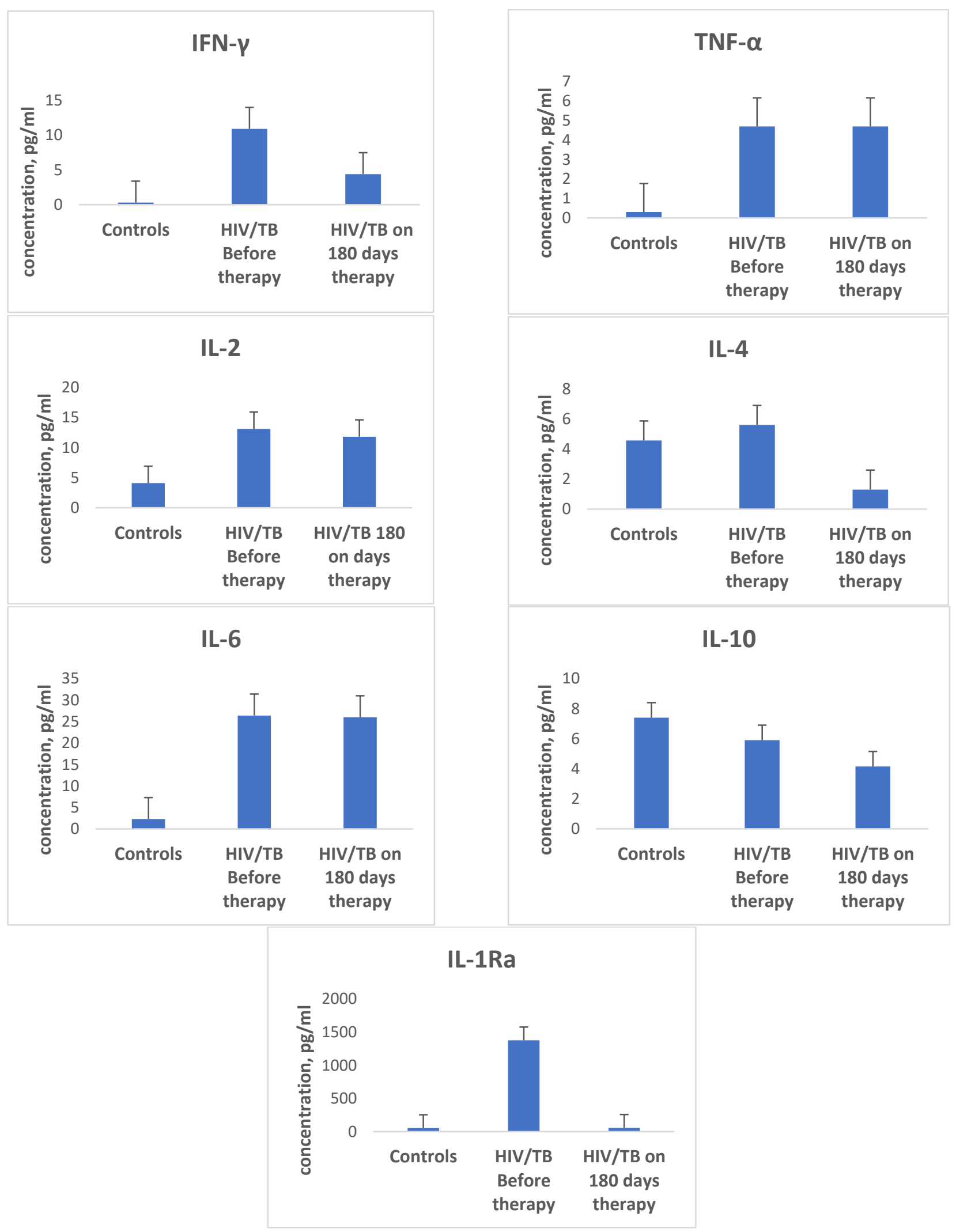

Figure 3. Plasma levels of different cytokines in patients with dual HIV/TB infection before and after dual therapy (therapy duration 180 days): interferon- $\gamma$ (IFN- $\gamma$ ), tumor necrosis factor- $\alpha$ (TNF- $\alpha$ ), interleukin-2 (IL-2), interleukin-4 (IL-4), interleukin-6 (IL-6), interleukin-10 (IL-10), and interleukin-1 receptor antagonist (IL-1RA). Bars represent standard deviation. 


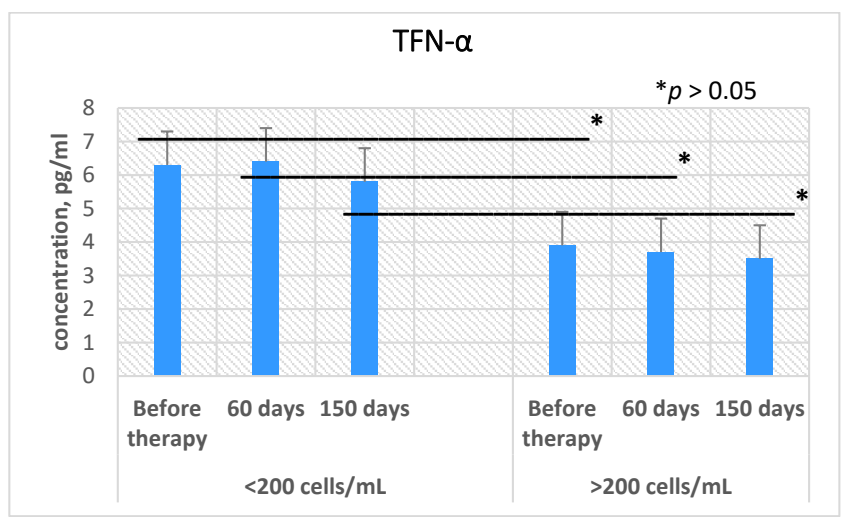

(A)

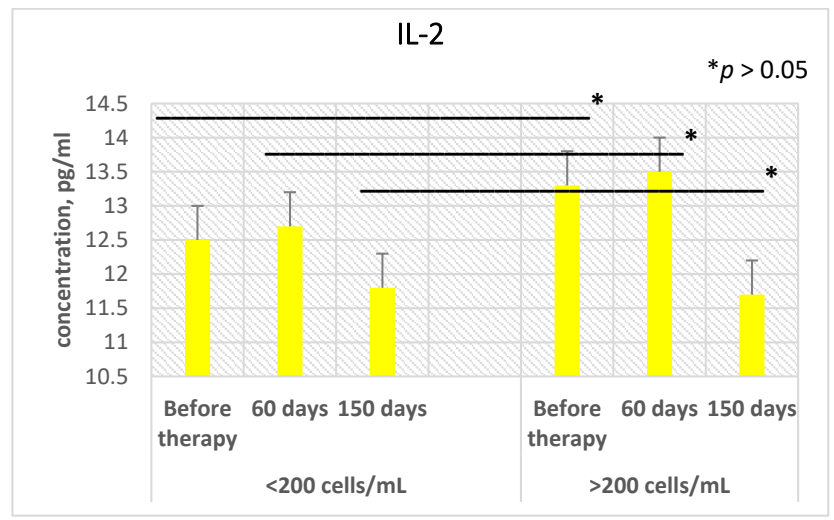

(B)

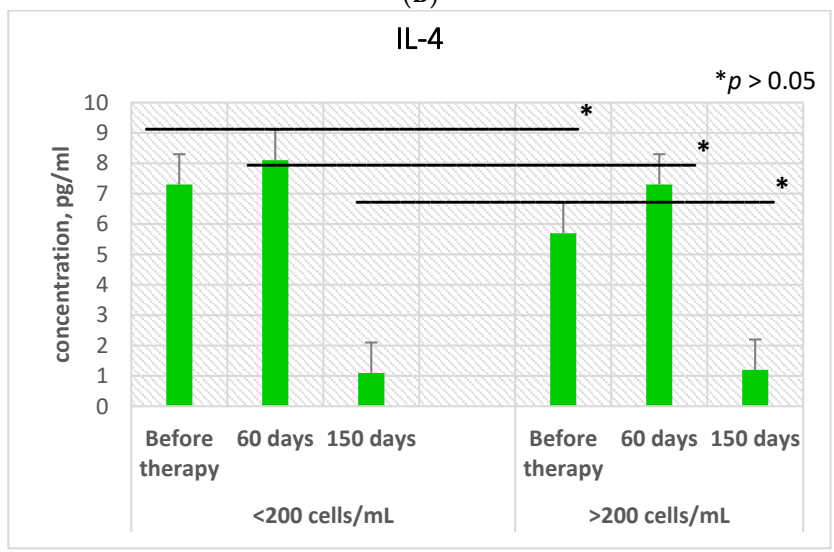

(C)

IL-10

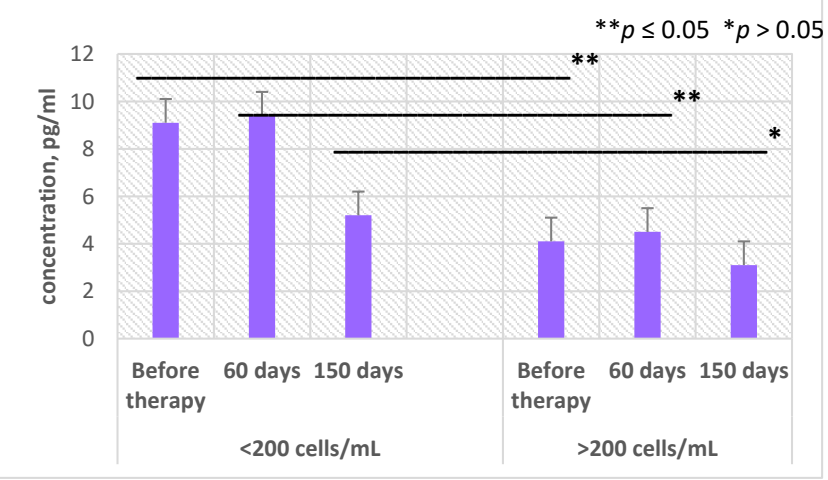

(D)

Figure 4. Cont. 


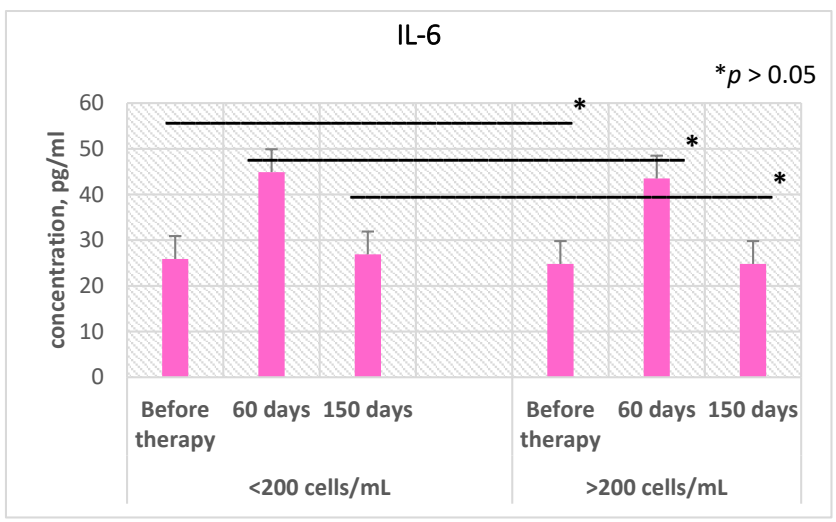

(E)

Figure 4. Plasma levels of different cytokines in patients with dual HIV/TB infection depending on the CD4 cell count: tumor necrosis factor- $\alpha$ (TNF- $\alpha)(A)$, interleukin-2 (IL-2) (B), interleukin-4 (IL-4) (C), interleukin-10 (IL-10) (D), and interleukin-6 (IL-6) (E). Bars represent standard deviation.

\subsection{Expression of the Interleukin-1 Receptor Antagonist (IL-1Ra)}

IL-1Ra is involved in the natural compensatory mechanism in IL-1-induced pathological processes and is a marker of the acute phase of inflammation. In patients with active pulmonary tuberculosis, local inflammation in the lower respiratory tract can cause an increased release of IL-1Ra, so the level of this pro-inflammatory cytokine may be more representative of lung diseases [34].

Presumably, the level of this cytokine may correlate with the clinical course of the disease, such as the degree of lung damage, fever, and weight loss. Taking into account the important role of IL-1Ra in $M$. tuberculosis infection, we decided to study the expression of this cytokine in more detail in a double HIV/TB infection. Therefore, patients who developed IRIS after 1.5-2 months of ART initiation $(n=16 / 15.2 \%)$ were also included in the study. The symptoms observed in HIV/TB patients who developed IRIS are presented in Table 2.

Table 2. Symptoms in the HIV/TB patients during development of IRIS $(n=16)$.

\begin{tabular}{cc}
\hline Symptoms & Frequency \\
\hline Fever only & $2(12.5 \%)$ \\
\hline Fever with lymph node enlargement & $7(43.8 \%)$ \\
\hline Fever with alveolar pneumonitis & $2(12.5 \%)$ \\
\hline Fever with abdominal lymphadenopathy & $2(12.5 \%)$ \\
\hline Abdominal lymphadenopathy only & $1(6.25 \%)$ \\
\hline Lymph node enlargement only & $2(12.5 \%)$ \\
\hline
\end{tabular}

Generalized lymphadenopathy prevailed among the systemic symptoms that developed with IRIS (43.8\%). The average duration of IRIS development after the start of ART was 75.02 ( \pm 19.14$)$ days in $62.5 \%$ (10) of patients and $119.01( \pm 14.17)$ days in $37.5 \%(6)$ of patients. When studying the expression level of IL-1Ra, it was found that in a group of patients with HIV/TB co-infection without IRIS, this indicator was on average almost four times $(p=0.001)$ higher than in patients with HIV and TB only, but it significantly decreased after 1.5-2 months of double therapy (Figure 5). 


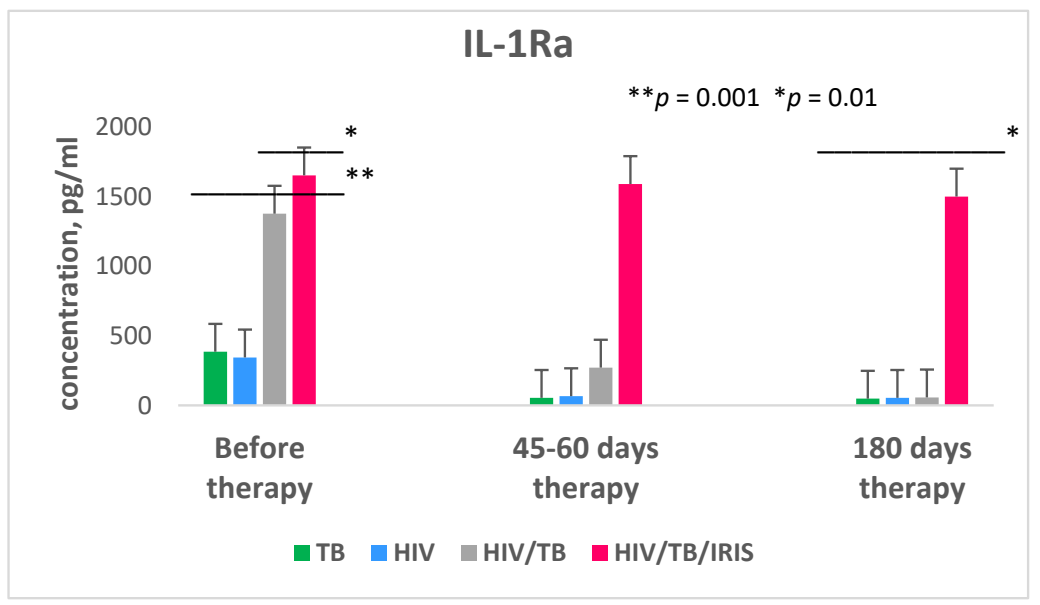

Figure 5. Plasma levels of interleukin-1 receptor antagonist (IL-1Ra) in patients with dual HIV/TB infection with and without immune reconstitution inflammatory syndrome (IRIS), HIV monoinfection, and TB monoinfection before and in the process of receiving therapy. For patients with HIV monoinfection before initiation of ART. For patients with TB monoinfection before initiation of ATT. For patients with HIV/TB before initiation of ART and ATT. Bars represent standard deviation.

After 6 months of therapy, the production of IL-1Ra in patients with HIV/TB without IRIS reached a level comparable to that in the group of patients with only HIV and with only TB $(p=0.002)$. In patients with HIV / TB co-infection who subsequently developed IRIS, the level of IL-1Ra expression before the initiation of ART was 4.8 times higher compared to the group of patients with TB monoinfection $(p=0.001)$ and almost 1.2 times higher than the same indicator compared to the group of patients with HIV/TB co-infection without IRIS $(p=0.01)$. At the same time, this indicator remained high throughout the entire period of therapy in patients with HIV/TB who developed IRIS. After the 180 days of therapy, the level of IL-1Ra expression in this group of patients was, on average, 28.5 times higher compared with other groups of patients $(p=0.001)$. The results of multivariate regression analysis showed a statistical trend towards an increase in the incidence of IRIS in patients with high IL-1Ra levels (in the range of 1550-2500 pg/mL): OR = 4.3 (95\%CI 3.7-14.12, $p=0.53$ ). It should be noted that patients with double HIV/TB infection, both with and without IRIS, initially did not differ significantly in the number of CD4+ cells and viral load (Table 3). After 6 months of therapy, in general, there were also no significant differences in these indicators (Table 3). The group of patients with IRIS had a slightly lower increase in CD4+ cells, but this was not statistically significant. Furthermore, no correlation was detected between the risk of developing TB-IRIS with forms of TB or with HIV transmission route (it is assumed that drug addiction may also be one of the factors of the development of IRIS).

Table 3. Characteristics of patients with HIV/TB co-infection with and without IRIS.

\begin{tabular}{|c|c|c|c|}
\hline Characteristics & $\begin{array}{l}\text { IRIS Neg } \\
(n=89)\end{array}$ & $\begin{array}{l}\text { IRIS Pos } \\
(n=16)\end{array}$ & $p$-Value \\
\hline \multicolumn{4}{|l|}{ TB forms $(\% / n)$ : } \\
\hline Pulmonary & $79.7(71)$ & $68.8(11)$ & 0.0001 \\
\hline Extrapulmonary & $10.1(9)$ & $12.5(2)$ & \\
\hline \multicolumn{4}{|l|}{ CD4+ count (cells $/ \mathrm{mm}^{3}$ ), IQR: } \\
\hline Before therapy & $114(7-380)$ & $112(5-357)$ & 0.9772 \\
\hline After therapy (180 days) & $393(66-703)$ & $381(40-509)$ & 0.7233 \\
\hline \multicolumn{4}{|c|}{ Viral load $\left(\log _{10}\right.$ copies/mL), IQR: } \\
\hline Before therapy & $6.8(1.9-7.01)$ & $5.5(1.9-6.1)$ & 0.5967 \\
\hline After therapy (180 days) & $1.7(1.2-1.9)$ & $1.7(1.3-1.9)$ & 0.9023 \\
\hline
\end{tabular}




\section{Discussion}

Interferon- $\gamma(\mathrm{IFN}-\gamma)$ and TNF- $\alpha$ play a key role in the anti-Mtb cytokine cascade, as they are associated with the formation and maintenance of granulomas [35,36]. Cells recruited into an infected lung control the infection by producing IFN- $\gamma$ in response to $M t b$ [37]. In patients with mutations in the genes encoding the synthesis of IFN- $\gamma$ and its receptor, violations in the formation of granulomas, a decrease in the production of IFN- $\gamma$, and a pronounced depression of antimycobacterial immunity are detected [38,39]. Interferon- $\gamma$ is also involved in the activation of macrophages and the induction of MHC-II synthesis, which leads to an increase in the functional activity of antigen-presenting cells, the induction of T-helpers, and an increase in the cytotoxicity of monocytes, leading to the accumulation of CD4+ T-lymphocytes and/or cytotoxic T-lymphocytes [40,41]. It has been shown that IFN- $\gamma$ reduces viral replication in infected macrophages [42], and dysregulation of its expression directly correlates with the progression of immunodeficiency $[43,44]$.

In this study, all groups of patients had increased secretion of IFN- $\gamma$ in comparison with the control group. However, compared to the group of patients with only HIV and only with $\mathrm{TB}$, the expression of IFN- $\gamma$ in patients with double infection was significantly reduced. The decreased secretion of IFN- $\gamma$ in HIV/TB patients revealed by us in comparison with the groups of patients with HIV monoinfection and TB monoinfection is consistent with the results of other researchers who also showed a reduced secretion of IFN- $\gamma$, both in HIV infection and in double HIV/TB infection [2,44-46]. Moreover, if in TB patients, this indicator became comparable with the values in the control group after 1.5 months of therapy and in HIV-positive patients on the second month of therapy, in patients with double infection, it occurred only after 6 months of therapy. Studies conducted by Osuji et al. [4] have shown that the reduced concentration of IFN- $\gamma$ can remain in HIV patients, even after 12 months of therapy. Partly, this may be explained by the fact that chronic HIV infection is characterized by the depletion of Th cells secreting IFN- $\gamma$ [2]. It is likely that HIV-1 infection leads to a modification of the antigen presentation in macrophages and dendritic cell lines, which in turn leads to the anergy of HIV-1-specific CD4+ and CD8+ T cells [40]. Although it is assumed that in HIV infection, the expression of IFN- $\gamma$ and its immunological functions are shifted more towards pro-inflammatory action than immunoregulatory functions [40,47], it is believed that IFN- $\gamma$ can affect the development of HIV infection by changing the expression of chemokine receptors and their ligands, leading to a change in the penetration of the virus into monocytic cells [42]. The inhibition of chemokine receptor expression induced by IFN- $\gamma$ may limit the recruitment of monocytes to the sites of development of the pathological process in TB and HIV infection, thereby contributing to chronic inflammation [42].

Tumor necrosis factor- $\alpha$ (TNF- $\alpha)$, along with INF- $\gamma$ and IL-2, plays an important role in the immunopathology of both HIV infection and TB. TNF- $\alpha$ is critically important for controlling bacterial growth during infection with $M$. tuberculosis due to phagocyteactivating functions and has an active role in the formation of granulomas [37,48-52]. It has been shown that anti-TNF- $\alpha$ therapy prevents the maturation of granulomas, promoting the free growth of $M t b$ [48,52]. In some cases, normal granuloma formation occurs during antiTNF- $\alpha$ therapy, but nevertheless, it is not possible to control mycobacterial infection [53]. At the same time, TNF- $\alpha$ activates HIV replication in macrophages, T-lymphocytes, and monocytes by activating the NF-kB transcription factor $[3,48,54]$. In this study, an increased expression of TNF- $\alpha$ was noted in HIV monoinfection and TB monoinfection compared to the control group, which indicates the activation of the immune response. This is in accordance with the data of other researchers who received similar results $[43,55-57]$. However, in a double HIV /TB infection, we noted a reduced level of TNF- $\alpha$ production compared to other groups of patients. This does not contradict the results of researchers who have demonstrated that HIV-infected patients have a reduced expression of TNF- $\alpha$ in the granuloma microenvironment [53]. De Castro Cunha et al. also showed reduced concentrations of TNF- $\alpha$ in patients with HIV/TB compared to patients with only HIV and only with TB [52]. At the same time, in our study, in patients with HIV/TB after 
6 months of ART, the level of TNF- $\alpha$ remained the same as before therapy. Probably, as in the case of IFN- $\gamma$ secretion, this can be explained by the depletion of T cells. Wong et al. hypothesized that due to the negative impact of HIV-1 on CD4+ cells, their pool decreases and consequently, there are fewer CD4+ cells that can produce TNF- $\alpha$ and IFN- $\gamma$ [48]. As a result, the remaining $\mathrm{T}$-cells function in an enhanced mode, which ultimately leads to their depletion [48]. De Noranha et al. showed that in HIV / TB co-infection, HIV-1 affects the process of granuloma formation, disrupting the production of TNF- $\alpha$, which leads to defective granuloma formation and necrosis and, as a result, $M t b$ dissemination [53].

Interleukin (IL-2), along with IFN- $\gamma$ and TNF- $\alpha$, also plays an important role in the maturation, proliferation, and functional activity of immunocompetent cells, which are restraining factors in the progression of both HIV infection and TB [58,59]. IL-2 activates T cells, NK cells, B cells, monocytes, macrophages, and neutrophils [60]. However, the role of IL-2 in HIV infection is ambiguous. With active T-cell proliferation, IL-2 can stimulate HIV replication in activated and proliferating T-lymphocytes [61,62]. At the same time, IL-2 reduces the expression of receptors on antigen-presenting cells, decreasing the rate of their infection with HIV-1 [63]. In addition, IL-2 reduces the apoptosis of T-lymphocytes and increases their survival [64]. In M. tuberculosis infection, IL-2 plays an important role in triggering the antimicrobial activity of macrophages and, together with IFN- $\gamma$ and TNF- $\alpha$, stimulates the ability of macrophages to kill $M t b$ [65]. We have shown that the level of IL-2 production in patients with double infection was significantly reduced compared to the groups of patients with only HIV and only TB, as well as with the control group. The reduced concentration of IL-2 in patients with HIV / TB co-infection was also demonstrated by a number of other researchers $[46,66]$. In this study, the level of IL-2 expression in the $\mathrm{HIV} / \mathrm{TB}$ group of patients after the initiation of ART remained almost the same as before therapy, which as in the case of IFN- $\gamma$ - and TNF- $\alpha$ secretion, is most likely due to the depletion of T cells. It is obvious that the reduced expression of INF- $\gamma$, IL-2, and TNF- $\alpha$ in patients with double HIV / TB infection indicates the suppression of the Th1 response.

Interleukin 4 (IL-4) is a pleiotropic cytokine produced by activated CD4+ T-lymphocytes, mast cells, and basophils and has multiple functions that modulate the immune response to various cell types [67]. In HIV infection, IL-4 differentially regulates the expression of CCR5 and CXCR4 co-receptors, which play a key role in HIV-1 infection, preventing the virus from entering the cell and its replication [68,69]. It has also been shown that the nucleotide polymorphism in the IL-4 gene (IL-4 2589T) prevents the progression of HIV infection by reducing the viral load [68]. At the same time, an increased expression of IL-4 leads to a greater susceptibility to $M t b$ infection $[70,71]$. A study conducted among medical professionals showed that those individuals whose peripheral blood mononuclear cells synthesized IL-4 in response to $M$. tuberculosis infection in vitro subsequently developed an active form of TB within 2-4 years [70,72]. Studies on Balb/c mice with IL-4 genes knocked out also proved that the absence of IL-4 leads to a decrease in Mtb growth [73]. Interleukin 10 (IL-10) is an anti-inflammatory cytokine secreted in response to systemic inflammation by monocytes, macrophages, T cells, and dendritic cells [74]. This cytokine inhibits the production of pro-inflammatory cytokines and the action of antigen-presenting cells, blocking the activation of T-lymphocytes by inhibiting the expression of MHC class II molecules [35]. Currently, there are conflicting data on the role of IL-10 in HIV infection. A number of researchers have shown that high levels of IL-10 inhibit the production of HIV-1 [75-78]. Conversely, other researchers have obtained contradictory data, demonstrating that an increased level of IL-10 promotes the active replication of HIV-1, inducing an enhanced expression of CCR5 and CXCR4 co-receptors $[79,80]$. In addition, it was found that high concentrations of IL-10 correlate with the increased expression of PD-1 (programmed death ligand-1) on monocytes [81], which leads to the depletion of T cells and the progression of HIV infection [82]. Studies conducted in vitro on human cell lines have demonstrated that blocking IL-10 can improve the immune response to HIV-1 [74]. At the same time, it was previously shown that IL-10 inhibits the apoptosis of IL-2-dependent T cells [83]. 
The role of IL-10 in $M t b$ infection is also not fully understood, but in vivo studies on a CBA/J mice model susceptible to $M t b$ infection have demonstrated that blocking IL-10 during chronic $M t b$ infection stabilized the pulmonary bacterial load and improved the survival of specimens [84]. The fact that high concentrations of Il-10 aggravate the course of TB infection is also confirmed by other studies in vivo on a model of transgenic mice (C57BL/6 mice model) producing an increased amount of IL-10. After infection with $M$. Tuberculosis, mice with IL-10 hypersecretion showed an accelerated progression of TB infection and signs of TB reactivation [85]. In this study, there was a significant decrease in the expression of IL-4 and IL-10 in patients with HIV/TB co-infection compared to patients with HIV monoinfection and TB monoinfection before ART. At the same time, the level of both cytokines in patients with HIV/TB was actually the same as in the control group, which indicates a deep failure of the immune system. It is assumed that, due to the persistently high viral load and constant immune activation observed in both HIV infection and TB, T-cells are depleted, and they lose their ability to function effectively [86,87]. However, in the process of receiving therapy, the level of IL-4 and IL-10 production increased slightly, and after 6 months of treatment, it reached the same level as in the group of patients with only HIV and only with TB. The reduced expression of IL-4 and IL-10 in double HIV / TB infection is in line with the earlier observations by our group [88] and by others [46]. Contradictory data were obtained by da Silva et al. and Osuji et al., who demonstrated an enhanced expression of IL-4 and IL-10 in HIV/TB co-infection $[4,56]$. The difference in the obtained results is probably due to the fact that the cohort of patients in our study significantly differed from the patient's groups in other studies by clinical and immunological indicators. In this study, the majority of patients were at the late stages of HIV infection (C3-67.8\%) with severe immunosuppression, and $46.1 \%$ of patients had disseminated TB, and $40.4 \%$ had infiltrative TB. Disseminated TB is a mycobacterial infection in which $M t b$ has spread from the lungs to other parts of the body through the blood or lymph system. As a result, generalized disseminated tuberculosis with foci in various organs or tuberculous sepsis develops. HIV infection also contributes to the dispersion of $\mathrm{Mbt}$ in the body. Infiltrative pulmonary tuberculosis is a secondary tuberculosis infection characterized by a widespread lesion of the lungs with an exudative type of inflammatory reaction and the formation of foci of caseous decay. In the case of further progression of infiltrative TB, two variants of development are possible: transition to caseous pneumonia or the disintegration of lung tissue with the formation of cavities. Both forms of TB in patients with late stages of HIV infection proceed with a pronounced intoxication syndrome. Thus, perhaps one of the factors explaining the reduced expression of those cytokines might be the serious condition of the patients, which influenced immunological deterioration. The revealed reduced production of IL-4 and IL-10 indicates that despite the fact that patients with HIV / TB co-infection were in the late stages of the disease, they did not have a shift towards the expression of Th2 class cytokines.

In a comparative study of the expression levels of a number of cytokines in patients with $\mathrm{HIV} / \mathrm{TB}$ co-infection depending on the CD4+ cell count (CD4+ $<200$ and CD4+ > 200 cells $/ \mathrm{mm}^{3}$ ), there was no significant difference in the production of IL-2 and IL- 4 cytokines before and after the start of therapy. The expression level of both cytokines remained almost unchanged, despite an increase in the number of CD4+ cells and a decrease in the viral load. Thus, the reduced level of expression of these cytokines is not directly associated with a decrease in the number of CD4+ cells since cell growth increased over time after the initiation of therapy. Presumably there are some other factors that affect the expression of these cytokines in patients with TB at late stages of HIV infection, which is the subject of future research. It is obvious that HIV infection and TB have an additive effect on the immune system, disrupting the secretion of cytokines. Higher levels of TNF- $\alpha$ and IL-10 production were observed in the group of patients with CD $4+<200 \mathrm{cells} / \mathrm{mm}^{3}$ compared to the group with CD4+ $>200$ cells $/ \mathrm{mm}^{3}$, which indicates more intense immune activation. However, in general, in patients with combined HIV/TB infection after the start 
of antiretroviral/anti-tuberculosis therapy, there was a delayed and incomplete recovery of the immune activity.

IL-6 is a multifunctional cytokine with both pro-inflammatory and anti-inflammatory effects produced in response to tissue damage and infections [89,90]. The biological role of IL-6, first of all, consists of the induction of regenerative mechanisms and the activation of immune defense: the activation and differentiation of $\mathrm{T}$ cells, maturation of $\mathrm{B}$ cells, and induction of synthesis/secretion of immunoglobulins, synthesis of C-reactive protein in the liver and enhancement of hematopoiesis [91,92]. IL-6 is induced instantly at the early stages after the infection of monocytes/macrophages, with a subsequent increase in its expression [93]. Numerous data indicate that the dysregulation of IL-6 expression is the main factor in the pathogenesis of chronic inflammatory and autoimmune diseases [94,95].

The results of our study revealed that in naive patients with HIV monoinfection, as well as in patients with double HIV/TB infection, IL-6 concentration levels were significantly increased compared to the control group, which is consistent with the data obtained by other researchers $[1,4,96-98]$. At the same time, the concentration level of IL-6 in the cohort of patients with HIV/TB exceeded the same indicator in the group of patients with HIV only. The enhanced expression of IL-6 demonstrated by our group in HIV-negative patients with active TB versus the group of healthy controls is also confirmed by the results of other studies [55,99]. However, if in the cohort of HIV-positive patients, the level of IL-6 gradually decreased in the process of receiving ART and became comparable with the control group, which is consistent with the data obtained by Osuji et al. [4] and Haissman et al. [100], in this study, in patients with HIV/TB co-infection, even after 6 months of therapy, IL-6 expression remained at the same high level as before ART. The detected pronounced increase in the level of IL-6 in HIV/TB patients with severe immunosuppression in the absence of inflammatory immune recovery syndrome (IRIS) indicated less effective immune recovery, given that the median CD4+ cell count in the group with CD4 $+<200$ cells $/ \mathrm{mm}^{3}$ was 57 cells $/ \mathrm{mm}^{3}$. Evidently, such a profound dysregulation of IL-6 production in patients with HIV/TB is explained by the synergistic effect of both infections and contributes to the development of both HIV and TB pathology. Thus, it has been shown that $M$. tuberculosis induces the dysregulation of pro-inflammatory cytokines and, in particular, activates the expression of IL-6 by phagocytes [55]. The increased expression of IL-6 induced by $M t b$ leads to the inhibition of the autophagy process in infected cells [101].

In the 1990s, it was shown that the increased expression of IL-6 enhances HIV replication by a translational mechanism, which in turn leads to an increase in the viral load, the infection of still uninfected T-cells and a further decrease in the expression of Th1 class cytokines [102]. According to recent studies, the HIV-1 vpr regulatory gene causes the degradation of TET2 DNA demethylase, which suppresses the induction of the IL-6 gene in HIV-1 infected macrophages, which subsequently leads to the stable IL-6 expression and increased HIV-1 replication [103]. Interleukin-6 (IL-6) also reduces the binding of TNF- $\alpha$ to macrophages, which leads to the antagonization of the antimycobacterial effect of TNF- $\alpha$ and, as a result, to a severe course of the TB process [46]. It is believed that IL-6 is a powerful activator of C/EBP (CCAAT-enhancer-binding protein) and that the effect of IL-6 on monocytes also leads to an increase in HIV-1 replication [93,104]. IL-6 hypersecretion promotes viral persistence, disrupting the polarization and functionality of Th1 cells, as well as the lytic ability of CD8+ cells [89]. The reduced concentration of anti-inflammatory cytokines IL-4 and IL-10, which play a protective role in TB and HIV infection, against the background of the elevated levels of cytokine IL-6, which stimulates HIV replication, indicates the progression of both diseases in patients with HIV/TB. The course of tuberculosis associated with HIV infection is characterized by a more severe clinical form of $\mathrm{TB}$, with an increase in the number of infiltrative, fibrous-cavernous, and disseminated forms. It was shown that the increased expression of the IL-6 gene correlates with the delayed dynamics of the resorption of infiltrates in the lung tissue and with the long-term preservation of respiratory complaints in patients during treatment [38]. Quite often, the symptoms of TB associated with HIV infection are non-specific. For this reason, 
the majority of clinicians note the difficulty of diagnosing tuberculosis in HIV-infected patients, especially at the stage of secondary diseases. As a result, the atypical course of TB in the late stages of HIV infection contributes to the growth of untimely diagnosis of tuberculosis in patients with HIV infection. During X-ray examination, a visible decay in the lung tissue is detected only when necrotic masses are rejected through the bronchi. Therefore, the absence of communication with the bronchus does not indicate the absence of destruction. In our study, $40.3 \%$ of patients who were aware of their HIV-positive status and ART-naïve before admission to the hospital were newly diagnosed with TB, and 59.7\% were newly diagnosed with HIV and TB. Those patients were admitted to the clinic at the late stages of HIV infection, the course of which was aggravated by undiagnosed and untreated TB. In this regard, early diagnosis of tuberculosis in patients with combined $\mathrm{HIV} / \mathrm{TB}$ infection is quite urgent. According to the data obtained by us, IL-6 concentrations in patients with HIV-monoinfection and TB-monoinfection against the background of treatment return to normal and become comparable with the control group (on day 75 and day 30, respectively). However, in patients with double HIV / TB infection, IL-6 levels do not decrease and remain enhanced despite the ongoing therapy. Therefore, we believe that an increased persistent level of IL-6 expression in the cohort of HIV/TB patients against the background of ART and reduced concentrations of IL-4 and IL-10 can serve as a possible marker of early detection of $M$. tuberculosis infection in HIV-infected individuals.

IL-1Ra is a cytokine produced mainly by macrophages and monocytes, as well as neutrophils, fibroblasts, endothelial, and dendritic cells in the acute phase of inflammation [105-107]. The mechanism of action of IL-1Ra consists of the blockade of the cellular receptor specific for interleukin- $1 \alpha$ and interleukin- $1 \beta$, as a result of which the activity of the inflammatory cytokine-interleukin-1-is regulated at the site of introduction and replication of viral agents, including the undesirable effects for the body resulting from its excessive production $[105,107]$. It is known that IL-1Ra plays an extremely important role in the immune response during $M t b$ infection, in particular, in restraining and preventing the spread of infection by the formation of granulomas [108-110]. In HIV infection, it has been shown that HIV induces the production of IL-1Ra at the early stages of infection $[111,112]$. In this study, it was revealed that the plasma level of IL-1Ra in patients with HIV/TB co-infection before the initiation of ART was quite high and significantly exceeded similar indicators in patients only with HIV and only with TB, but already at 45-60 days of therapy, it sharply decreased, and after 6 months of therapy, it reached a level comparable to the same indicator with the control group and two other groups of patients. The data obtained by our group are confirmed by the results of Hoel et al., who showed that patients with HIV / TB co-infection had an increased expression of IL-1Ra before the start of ART and anti-tuberculosis therapy, followed by a decrease in the level of controls, which indicated the success of the therapy [106]. However, a different picture was observed in patients with HIV / TB who developed IRIS associated with TB (TB-IRIS) after 2-3 months of ART. In these patients, the level of IL-1Ra expression was 1.2 times higher than in patients with HIV / TB without TB-IRIS and remained almost at the same level during 6 months of therapy. TB-IRIS is characterized by a paradoxical deterioration of tuberculosis manifestations or even the development of new tuberculosis symptoms in HIV-infected patients after the start of ART, despite the increase in CD4+ cells and decrease in viral load [113-119]. Usually, TB-IRIS develops within 2-3 months after the start of ART [117,120]. This immunopathological reaction evolves in 4-54\% of cases of HIV/TB infection [33,119-125]. The average duration of TB-IRIS symptoms is about 1-3 months [126-129], and in some cases, this condition can persist for more than 1 year [33,119,123,124,130-132]. In most patients, TB-IRIS disappears spontaneously, without leading to significant mortality. However, in patients, as in this study, who are at the late stages of HIV infection (the median CD4+ cell count was 114 cells $/ \mathrm{mm}^{3}$ ), the presence of this syndrome can cause severe local and systemic inflammatory reactions, which in turn can lead to early mortality [133-135]. Although it is believed that the main risk factors for the development of TB-IRIS are a low initial level of CD4+ cells and a high initial viral load [121,126-128], nevertheless, in 
this study, the percentage of cases of TB-IRIS was relatively small and amounted to $15.2 \%$, which is consistent with the data of other researchers who identified the frequency of TB-IRIS in patients with HIV/TB co-infection to be also at the level of $11-15 \%[116,119,136]$. There were no cases of fatal outcomes among the studied cohort of HIV/TB patients with TB-IRIS, and after 6 months of therapy, on the whole, this group of patients did not show a significant difference in $\mathrm{CD} 4+$ cell growth and a decrease in viral load compared to the group of HIV / TB patients without TB-IRIS. However, the duration and severity of the systemic symptoms (fever with lymph node enlightenment, $43.8 \%$ ) that developed in patients with TB-IRIS indicate that perhaps the duration of anti-tuberculosis therapy should be prolonged, and the application of ART delayed up to 12 weeks, as recommended by the New York State Department of Health (NYSDOH) AIDS Institute Guidelines [137]. According to the WHO clinical recommendations, ART should be started within 2-8 weeks after the initiation of TB therapy, depending on the number of CD4+ cells [138]. Although the early initiation of ART improves the survival of patients with a low number of CD4+ cells, there is insufficient evidence to confirm or refute the advantage of the early initiation of ART for the survival of HIV / TB patients with a CD4+ cell count $>50$ cells $/ \mathrm{mm}^{3}$, but at the same time, the early initiation of ART doubles the frequency of TB-IRIS in this cohort of patients, regardless of the number of CD4+ cells [137,139].

Undoubtedly, this study has certain limitations due to the small number of HIV/TB patients with TB-IRIS. Nevertheless, the high level of IL-1Ra expression (in the range of $1550-2500 \mathrm{pg} / \mathrm{mL}$ ) even before the start of anti-tuberculosis therapy and ART was detected in HIV / TB patients with newly diagnosed TB who subsequently developed TB-IRIS vs. similar indicator in HIV/TB cohort without IRIS can be considered as a potential predictive biomarker of the development of TB-IRIS and the success of drug therapy at the very beginning of treatment.

In addition, a 4-year follow-up of a cohort of patients with TB monoinfection conducted by Sivro et al. showed that a high level of IL-1Ra and IL-6 expression definitely correlated with TB relapse [140]. Unfortunately, within the framework of this study, we did not have the opportunity to follow patients with HIV/TB for more than 6 months, but we can assume with a high degree of probability that the results obtained by Sivro et al. will also be true for a cohort of patients with HIV/TB co-infection. Moreover, as in the case of elevated IL-6 expression, high levels of IL-1Ra in patients with HIV monoinfection are associated with an increased risk of cardiovascular diseases; in particular, a 1.5-fold increased risk of myocardial infarction $[106,141]$. Taking this into account, to improve the effectiveness of therapy, physicians should pay attention to the increased level of expression of these cytokines.

\section{Conclusions}

In HIV infection, as the disease progresses, a shift occurs from the secretion of Th1class cytokines to the secretion of Th2-class cytokines [2,3,63,142]. If at the beginning of the disease, there is an increased expression of Th1 class cytokines, such as IL-2 and IFN- $\gamma$, then at later stages, their production decreases, while the production of Th2 class cytokines, IL-4, IL-10 and TNF- $\alpha$ increases [2]. Our study revealed that during a double HIV/TB infection, both Th1 and Th2 immune responses are suppressed. Reduced levels of pro- and anti-inflammatory cytokines in patients with double infection indicate a prolonged dysregulation of the immune response and increased severity of the disease in pulmonary/extrapulmonary tuberculosis in patients with HIV/TB. The monitoring of patients with HIV / TB co-infection in the process of receiving therapy showed that a double $\mathrm{HIV} / \mathrm{TB}$ infection is characterized by delayed and incomplete recovery of immune activity.

The level of IL-6 secretion in HIV/TB co-infection with newly diagnosed HIV, TB, and previously untreated HIV, both before the initiation of ART and during 6 months of therapy, remained constantly high. Considering that patients with infiltrative pulmonary TB against the background of HIV infection may have elements of destructive decay that are not detected radiologically but are reflected in the immune response, an increased level 
of IL-6 expression against the background of reduced concentrations of IL-4 and IL-10 can serve as a marker for the early detection of $M$. tuberculosis infection in HIV-infected individuals. The high level of IL-1Ra expression even before the start of anti-tuberculosis therapy and ART detected in HIV/TB patients who subsequently developed TB-IRIS can be considered as a potential predictive biomarker of the development of TB-IRIS and the success of drug therapy at the very beginning of the treatment. Furthermore, the duration and severity of the systemic symptoms (fever with lymph node enlightenment, 43.8\%) that developed in patients with TB-IRIS indicate that perhaps the time of anti-tuberculosis therapy should be prolonged and the application of ART delayed by up to 12 weeks. Taking into account the important role that cytokines play in the pathogenesis of HIV infection and TB by regulating innate and adaptive immune responses, the subject of future research is the long-term follow-up ( $>2$ years) of patients with HIV / TB co-infection and the study of the correlation of changes in the immune status with concomitant pathologies.

Author Contributions: Conceptualization, M.N., O.S., V.Z. and V.P.; Methodology, M.N., K.R., A.K., U.K., I.R. and A.S.; Data analysis, M.N. and O.S.; Drawing up a plan for working with patients, supervising, and coordinating the collection of clinical samples, V.P., A.S., I.R., A.K. and U.K.; Survey of patients and collection of clinical material, M.N., I.R., A.K. and U.K.; Writing-original draft preparation, M.N.; Writing-Review and editing, M.N., O.S., V.Z. and V.P.; Visualization, M.N. and K.R.; Supervision, M.N.; Funding acquisition, O.S. and V.Z. All authors have read and agreed to the published version of the manuscript.

Funding: The study was carried out with the Collective Usage Center "I.I.Mechnikov NIIVS", Moscow, Russia; RFBR \#0525-2019-0040.

Institutional Review Board Statement: The study was conducted according to the guidelines of the Declaration of Helsinki and approved by the Biomedical Ethics Committee of the I.I. Mechnikov Institute of Vaccines and Sera, Moscow, Russia (protocol \#1/01/17/2018).

Informed Consent Statement: All the participants gave written informed consent to participate in the study.

Data Availability Statement: Data available upon request from the authors.

Conflicts of Interest: Authors declare no conflict of interest.

\section{References}

1. French, M.A.; Cozzi-Lepri, A.; Arduino, R.C.; Johnson, M.; Achira, A.C.X.; Landay, A. Plasma levels of cytokines and chemokines and the risk of mortality in HIV-infected individuals: A case control analysis nested in a large clinical trial. AIDS 2015, $29,847-851$. [CrossRef]

2. Kaur, R.; Dhakad, M.S.; Goal, R.; Bhalla, P.; Dewan, R. Study of TH1/TH2 cytokine profiles in HIV/AIDS patients in a tertiary care hospital India. J. Med. Microbiol. Diagn. 2016, 5, 214-221. [CrossRef]

3. Reuter, M.A.; Pombo, C.; Betts, M.R. Cytokine production and dysregulation in HIV pathogenesis: Lessons for development of therapeutics and vaccines. Cytokine Growth Factor Rev. 2012, 23, 181-191. [CrossRef]

4. Osuji, F.N.; Onyenekwe, C.C.; Ahaneku, J.E.; Ukibe, N.R. The effects of highly active antiretroviral therapy on the serum levels of pro-inflammatory and anti-inflammatory cytokines in HIV infected subjects. J. Biomed. Sci. 2018, 25, 88. [CrossRef]

5. Hunt, P.W. HIV and Inflammation: Mechanisms and Consequences. Curr. HIV/AIDS Rep. 2012, 9, 139-147. [CrossRef]

6. Jacobs, J.L.; Halvas, E.K.; Tosiano, M.A.; Mellors, J.W. Persistent HIV-1 Viremia on Antiretroviral Therapy: Measurement and Mechanisms. Front. Microbiol. 2019, 15, 2383. [CrossRef]

7. Hoenigl, M.; Kessler, H.H.; Gianella, S. Editorial: HIV-Associated Immune Activation and Persistent Inflammation. Front. Immunol. 2019, 18, 2858. [CrossRef]

8. Catalfamo, M.; Le Saout, C.; Lane, H.C. The role of cytokines in the pathogenesis and treatment of HIV infection. Cytokine Growth Factor Rev. 2012, 23, 207-214. [CrossRef] [PubMed]

9. Zicari, S.; Sessa, L.; Cotugno, N.; Ruggiero, A.; Morrocchi, E.; Concato, C.; Rocca, S.; Zangari, P.; Manno, E.C.; Palma, P. Immune Activation, Inflammation, and Non-AIDS Co-Morbidities in HIV-Infected Patients under Long-Term ART. Viruses 2019, 27, 200. [CrossRef]

10. Osoti, A.; Temu, T.M.; Kirui, N.; Ngetich, E.K.; Kamano, J.H.; Page, S.; Farquhar, C.; Bloomfield, G.S. Metabolic Syndrome Among Antiretroviral Therapy-Naive Versus Experienced HIV-Infected Patients Without Preexisting Cardiometabolic Disorders in Western Kenya. AIDS Patient Care STDS 2018, 32, 215-222. [CrossRef]

11. Swami, A. Metabolic Syndrome and HIV Infection. J. HIV Retrov. 2016, 2, 9. [CrossRef] 
12. Li Vecchi, V.; Maggi, P.; Rizzo, M.; Montalto, G. The metabolic syndrome and HIV infection. Curr. Pharm. Des. 2014, 20 , 4975-5003. [CrossRef]

13. So-Armah, K.; Benjamin, L.A.; Bloomfield, G.S.; Feinstein, M.J.; Hsue, P.; Njuguna, B.; Freiberg, M.S. HIV and cardiovascular disease. Lancet HIV 2020, 7, E279-E293. [CrossRef]

14. Alonso, A.; Barnes, A.E.; Guest, J.L.; Shah, A.; Shao, I.Y.; Marconi, V. HIV Infection and Incidence of Cardiovascular Diseases: An Analysis of a Large Healthcare Database. J. Am. Heart Assoc. 2019, 8, e012241. [CrossRef]

15. Hsue, P.Y.; Waters, D.D. HIV infection and coronary heart disease: Mechanisms and management. Nat. Rev. Cardiol. 2019, 16, 745-759. [CrossRef]

16. Nosik, M.; Lavrov, V.; Svitich, O. HIV Infection and Related Mental Disorders. Brain Sci. 2021, 11, 248. [CrossRef]

17. Nickoloff-Bybel, E.A.; Calderon, T.M.; Gaskill, P.J.; Berman, J.W. HIV Neuropathogenesis in the Presence of a Disrupted Dopamine System. J. Neuroimmune Pharmacol. 2020, 15, 729-742. [CrossRef]

18. Olivier, I.S.; Cacabelos, R.; Naidoo, V. Risk Factors and Pathogenesis of HIV-Associated Neurocognitive Disorder: The Role of Host Genetics. Int. J. Mol. Sci. 2018, 19, 3594. [CrossRef]

19. Sacktor, N.; Skolasky, R.L.; Seaberg, E.; Munro, C.; Becker, J.T.; Martin, E.; Ragin, A.; Levine, A.; Miller, E. Prevalence of HIV-associated neurocognitive disorders in the multicenter AIDS cohort study. Neurology 2016, 86, 334-340. [CrossRef]

20. Franzetti, M.; Ricci, E.; Bonfanti, P. The Pattern of Non-AIDS-defining Cancers in the HIV Population: Epidemiology, Risk Factors and Prognosis. A Review. Curr. HIV Res. 2019, 17, 1-12. [CrossRef]

21. Nagata, N.; Nishijima, T.; Niikura, R.; Yokoyama, T.; Matsushita, Y.; Watanabe, K.; Teruya, K.; Kikuchi, Y.; Akiyama, J.; Yanase, M.; et al. Increased risk of non-AIDS-defining cancers in Asian HIV-infected patients: A long-term cohort study. BMC Cancer 2018, 18, 1066. [CrossRef]

22. Raffetti, E.; Albini, L.; Gotti, D.; Segala, D.; Maggiolo, F.; di Filippo, E.; Saracino, A.; Ladisa, N.; Lapadula, G.; Fornabaio, C.; et al. MASTER Cohort. Cancer incidence and mortality for all causes in HIV-infected patients over a quarter century: A multicentre cohort study. BMC Public Health 2015, 15, 235. [CrossRef] [PubMed]

23. Calabresi, A.; Ferraresi, A.; Festa, A.; Scarcella, C.; Donato, F.; Vassallo, F.; Limina, R.; Castelli, F.; Quiros-Roldan, E. Brescia HIV Cancer Study Group. Incidence of AIDS-defining cancers and virus-related and non-virus-related non-AIDS-defining cancers among HIV-infected patients compared with the general population in a large health district of Northern Italy, 1999-2009. HIV Med. 2013, 14, 481-490. [CrossRef]

24. Brites-Alves, C.; Luz, E.; Netto, E.M.; Ferreira, T.; Diaz, R.S.; Pedroso, C.; Page, K.; Brites, C. Immune Activation, Proinflammatory Cytokines, and Conventional Risks for Cardiovascular Disease in HIV Patients: A Case-Control Study in Bahia, Brazil. Front. Immunol. 2018, 9, 1469. [CrossRef] [PubMed]

25. Rajasuriar, R.; Khoury, G.; Kamarulzaman, A.; Cameron, P.U.; Lewin, S.R. Persistent immune activation in chronic HIV infection: Do any interventions work? AIDS 2013, 27, 1199-1208. [CrossRef] [PubMed]

26. Lam, A.; Prabhu, R.; Gross, C.M.; Riesenberg, L.A.; Singh, V.; Aggarwal, S. Role of apoptosis and autophagy in tuberculosis. Am. J. Physiol. Lung Cell. Mol. Physiol. 2017, 313, L218-L229. [CrossRef] [PubMed]

27. de Martino, M.; Lodi, L.; Galli, L.; Chiappini, E. Immune Response to Mycobacterium tuberculosis: A Narrative Review. Front. Pediatr. 2019, 7, 350. [CrossRef]

28. Jo, E.-K. Autophagy as an innate defense against mycobacteria. Pathog. Dis. 2013, 67, 108-118. [CrossRef]

29. Sullivan, Z.A.; Wong, E.B.; Ndung'u, T.; Kasprowicz, V.O.; Bishai, W.R. Latent and Active Tuberculosis Infection Increase Immune Activation in Individuals Co-Infected with HIV. EBioMedicine 2015, 2, 334-340. [CrossRef]

30. Foti, M. Chapter 1-Introduction to Cytokines as Tissue Regulators in Health and Disease. In Cytokine Effector Functions in Tissues; Elsevier Inc.: Amsterdam, The Netherlands, 2017; pp. 3-30. [CrossRef]

31. Arunabha, R.; Jagdish, J. Cytokines and their Role in Health and Disease: A Brief Overview. MOJ Immunol. 2016, 4, 1-9. [CrossRef]

32. Chung, K.F. Cytokines in chronic obstructive pulmonary disease. Eur. Respir. J. 2001, 18, 50s-59s. [CrossRef]

33. Meintjes, G.; Lawn, S.D.; Scano, F.; Maartens, G.; French, M.A.; Worodria, W.; Elliott, J.H.; Murdoch, D.; Wilkinson, R.J.; Seyler, C.; et al. Tuberculosis-associated immune reconstitution inflammatory syndrome: Case definitions for use in resource limited settings. Lancet Infect. Dis. 2008, 8, 516-523. [CrossRef]

34. Tsao, T.; Li, L.; Hsieh, M.; Liao, S.-K.; Chang, K.S.S. Soluble TNF- $\alpha$ receptor and IL-1 receptor antagonist elevation in BAL in active pulmonary TB. Eur. Respir. J. 1999, 14, 490-495. [CrossRef] [PubMed]

35. Cavalcanti, Y.V.; Brelaz, M.C.; Neves, J.K.; Ferraz, J.C.; Pereira, V.R. Role of TNF-Alpha, IFN-Gamma, and IL-10 in the Development of Pulmonary Tuberculosis. Pulm. Med. 2012, 2012, 745483. [CrossRef]

36. Lahey, T.; Sheth, S.; Matee, M.; Arbeit, R.; Horsburgh, C.R.; Mtei, L.; Mackenzie, T.; Bakari, M.; Vuola, J.M.; Pallangyo, K.; et al. Interferon $\gamma$ responses to mycobacterial antigens protect against subsequent HIV-associated tuberculosis. J. Infect. Dis. 2010, 202, 1265-1272. [CrossRef]

37. Pawlowski, A.; Jansson, M.; Skold, M.; Rottenberg, M.E.; Kallenius, G. Tuberculosis and HIV Co-Infection. PLoS Pathog. 2012, 8, e1002464. [CrossRef] [PubMed]

38. Mezentseva, M.V.; Stakhanov, V.A.; Zakharova, M.V.; Zotova, I.F.; Tregubova, M.I.; Shapoval, I.M. Cytokines as markers of the infiltrative pulmonary tuberculosis developement. Russ. J. Infect. Immun. 2011, 1, 367-372. [CrossRef] 
39. Zhang, S.-Y.; Boisson-Dupuis, S.; Chapgier, A.; Yang, K.; Bustamante, J.; Puel, A.; Picard, C.; Abel, L.; Jouanguy, E.; Casanova, J.-L. Inborn errors of interferon (IFN)-mediated immunity in humans: Insights into the respective roles of IFN- $\alpha / \beta$, IFN- $\gamma$, and IFN- $\lambda$ in host defense. Immunol. Rev. 2008, 226, 29-40. [CrossRef] [PubMed]

40. Roff, S.R.; Noon-Song, E.N.; Yamamoto, J.K. The significance of interferon- $\gamma$ in HIV-1 pathogenesis, therapy, and prophylaxis. Front. Immunol. 2014, 4, 498. [CrossRef] [PubMed]

41. Ayatollahi Mousavi, S.A.; Asadikaram, G.; Nakhaee, N.; Izadi, A. Plasma Levels of IFN- $\gamma$, IL-4, IL-6 and IL-17 in HIV-Positive Patients with Oral Candidiasis. Jundishapur J. Microbiol. 2016, 9, e32021. [CrossRef]

42. Creery, D.; Weiss, W.; Lim, W.T.; Aziz, Z.; Angel, J.B.; Kumar, A. Down-regulation of CXCR-4 and CCR-5 expression by interferongamma is associated with inhibition of chemotaxis and human immunodeficiency virus (HIV) replication but not HIV entry into human monocytes. Clin. Exp. Immunol. 2004, 137, 156-165. [CrossRef]

43. Oh, M.D.; Kang, C.I.; Kim, U.S.; Kim, N.J.; Lee, B.; Kim, H.B.; Choe, K.W. Cytokine responses induced by Mycobacterium tuberculosis in patients with HIV-1 infection and tuberculosis. Int. J. Infect. Dis. 2005, 9, 110-116. [CrossRef]

44. Salvaggio, A.; Balotta, C.; Galli, M.; Clerici, M. CD4 count in HIV infection is positively correlated to interferon-gamma and negatively correlated to interleukin-10 in vitro production. AIDS 1996, 10, 449-451. [CrossRef]

45. Bordón, J.; Plankey, M.W.; Young, M.; Greenblatt, R.M.; Villacres, M.C.; French, A.L.; Zhang, J.; Brock, G.; Appana, S.; Herold, B.; et al. Lower levels of interleukin-12 precede the development of tuberculosis among HIV-infected women. Cytokine 2011, 56, 325-331. [CrossRef] [PubMed]

46. Bal, A.M.; Lakhashe, S.K.; Thakar, M.R.; Tripathy, S.P.; Paranjape, R.S. Dysregulation of proinflammatory and regulatory cytokines in HIV infected persons with active tuberculosis. Cytokine 2005, 30, 275-281. [CrossRef]

47. Naranbhai, V.; Abdool Karim, S.S.; Altfeld, M.; Samsunder, N.; Durgiah, R.; Sibeko, S.; Abdool Karim, Q.; Carr, W.H. Innate immune activation enhances HIV acquisition in women, diminishing the effectiveness of tenofovir rmicrobicide gel. J. Infect. Dis. 2012, 206, 993-1001. [CrossRef]

48. Wong, K.; Nguyen, J.; Blair, L.; Banjanin, M.; Grewal, B.; Bowman, S.; Boyd, H.; Gerstner, G.; Cho, H.J.; Panfilov, D.; et al. Pathogenesis of Human Immunodeficiency Virus-Mycobacterium tuberculosis Co-Infection. J. Clin. Med. 2020, 9, 3575. [CrossRef]

49. Domingo-Gonzalez, R.; Prince, O.; Cooper, A.; Khader, S.A. Cytokines and Chemokines in Mycobacterium tuberculosis Infection. Microbiol. Spectr. 2016, 4, 18. [CrossRef]

50. Nemeth, J.; Winkler, H.M.; Boeck, L.; Adegnika, A.A.; Clement, E.; Toung, M.M.; Kremsner, P.G.; Winkler, S. Specific cytokine patterns of pulmonary tuberculosis in Central Africa. Clin. Immunol. 2011, 138, 50-59. [CrossRef] [PubMed]

51. Mattos, A.M.M.; de Almeida, C.S.; Franken, K.L. Increased IgG1, IFN-gamma, TNF-alpha and IL-6 responses to Mycobacterium tuberculosis antigens in patients with tuberculosis are lower after chemotherapy. Int. Immunol. 2010, 22, 775-782. [CrossRef] [PubMed]

52. De Castro Cunha, R.M.; Kallas, E.G.; Rodrigues, D.S.; Nascimento Burattini, M.; Salomao, R. Interferon-g and tumour necrosis factor-alpha production by CD4+T and CD8+T lymphocytes in AIDS patients with tuberculosis. Clin. Exp. Immunol. 2005, 140, 491-497. [CrossRef]

53. De Noronha, A.L.; Báfica, A.; Nogueira, L.; Barral, A.; Barral-Netto, M. Lung granulomas from Mycobacterium tuberculosis/HIV-1 co-infected patients display decreased in situ TNF production. Pathol. Res. Pract. 2008, 204, 155-161. [CrossRef]

54. Kedzierska, K.; Crowe, S.M.; Turville, S.; Cunningham, A.L. The influence of cytokines, chemokines and their receptors on HIV-1 replication in monocytes and macrophages. Rev. Med. Virol. 2003, 13, 39-56. [CrossRef] [PubMed]

55. Joshi, L.; Ponnana, M.; Sivangala, R.; Chelluri, L.K.; Nallari, P.; Penmetsa, S.; Valluri, V.; Gaddam, S. Evaluation of TNF- $\alpha$, IL-10 and IL-6 Cytokine Production and Their Correlation with Genotype Variants amongst Tuberculosis Patients and Their Household Contacts. PLoS ONE 2015, 10, e0137727. [CrossRef]

56. Da Silva, T.P.; Giacoia-Gripp, C.B.; Schmaltz, C.A.; Sant Anna, F.M.; Rolla, V.; Morgado, M.G. T Cell Activation and Cytokine Profile of Tuberculosis and HIV-Positive Individuals during Antituberculous Treatment and Efavirenz-Based Regimens. PLoS ONE 2013, 8, e66095. [CrossRef]

57. Lawn, S.D.; Butera, S.T.; Folks, T.M. Contribution of immune activation to the pathogenesis and transmission of human immunodeficiency virus type 1 infection. Clin. Microbiol. Rev. 2001, 14, 753-777. [CrossRef]

58. Green, A.M.; DiFazio, R.; Joanne, L.; Flynn, J.A.L. IFN- $\gamma$ from CD4 T Cells Is Essential for Host Survival and Enhances CD8 T Cell Function during Mycobacterium tuberculosis Infection. J. Immunol. 2013, 190, 270-277. [CrossRef]

59. Subramanyam, S.; Hanna, L.E.; Venkatesan, P.; Sankaran, K.; Narayanan, P.R.; Swaminathan, S. HIV alters plasma and M tuberculosis-induced cytokine production in patients with tuberculosis. J. Interferon Cytokine Res. 2004, 24, 101-106. [CrossRef]

60. Shachar, I.; Karin, N. The dual roles of inflammatory cytokines and chemokines in the regulation of autoimmune diseases and their clinical implications. J. Leukoc. Biol. 2013, 93, 51-61. [CrossRef]

61. Freeman, M.L.; Shive, C.L.; Nguyen, T.P.; Younes, S.A.; Panigrahi, S.; Lederman, M.M. Cytokines and T-Cell Homeostasis in HIV Infection. J. Infect. Dis. 2016, 214 (Suppl. 2), S51-S57. [CrossRef]

62. Vatakis, D.N.; Bristol, G.; Wilkinson, T.A.; Chow, S.A.; Zack, J.A. Immediate activation fails to rescue efficient human immunodeficiency virus replication in quiescent CD4+ T cells. J. Virol. 2007, 81, 3574-3582. [CrossRef] [PubMed]

63. Hardy, G.A.; Imami, N.; Sullivan, A.K.; Pires, A.; Burton, C.T.; Nelson, M.R.; Gazzard, B.G.; Gotch, F.M. Reconstitution of CD4+ T cell responses in HIV-1 infected individuals initiating highly active antiretroviral therapy (HAART) is associated with renewed interleukin-2 production and responsiveness. Clin. Exp. Immunol. 2003, 134, 98-106. [CrossRef] 
64. Borthwick, N.J.; Akbar, A.A.; Buckley, C.; Pilling, D.; Salmon, M.; Jewell, A.P.; Yong, K.L. Transendothelial migration confers a survival advantage to activated T lymphocytes: Role of LFA-1/ICAM-1 interactions. Clin. Exp. Immunol. 2003, 134, $246-252$. [CrossRef]

65. Santoro-Lopes, G.; de Pinho, A.M.F.; Harrison, L.H.; Schechter, M. Reduced Risk of Tuberculosis among Brazilian Patients with Advanced Human Immunodeficiency Virus Infection Treated with Highly Active Antiretroviral Therapy. Clin. Infect. Dis. 2002, 34, 543-546. [CrossRef] [PubMed]

66. Wanchu, A.; Bhatnagar, A.; Talreja, J.; Sapra, S.; Suryanarayana, B.S.; Suresh, P. Immunophenotypic and intracellular cytokine profile of Indian patients with tuberculosis with and without human immunodeficiency virus co-infection. Indian J. Chest Dis. Allied Sci. 2009, 51, 207-211. [PubMed]

67. Chatterjee, A.; Rathore, A.; Dhole, T.N. Association of IL-4 589 C/T promoter and IL-4RalphaI50V receptor polymorphism with susceptibility to HIV-1 infection in North Indians. J. Med. Virol. 2009, 81, 959-965. [CrossRef] [PubMed]

68. Nakayama, E.E.; Meyer, L.; Iwamoto, A.; Persoz, A.; Nagai, Y.; Rouzioux, C.; Delfraissy, J.F.; Debre, P.; Mcllroy, D.; Theodorou, I.; et al. SEROCO Study Group. Protective effect of interleukin-4 -589T polymorphism on human immunodeficiency virus type 1 disease progression: Relationship with virus load. J. Infect. Dis. 2002, 185, 1183-1186. [CrossRef]

69. Wang, J.; Roderiquez, G.; Oravecz, T.; Norcross, M.A. Cytokine regulation of human immunodeficiency virus type 1 entry and replication in human monocytes/macrophages through modulation of CCR5 expression. J. Virol. 1998, 72, 7642-7647. [CrossRef]

70. Rook, G.A.W.; Hernandez-Pando, R.; Dheda, K.; Seah, G.T. IL-4 in tuberculosis: Implications for vaccine design. Trends Immunol. 2004, 25, 483-488. [CrossRef] [PubMed]

71. Dlugovitzky, D.; Bay, M.L.; Rateni, L.; Fiorenza, G.; Vietti, L.; Farroni, M.A.; Bottasso, O.A. Influence of disease severity on nitrite and cytokine production by peripheral blood mononuclear cells (PBMC) from patients with pulmonary tuberculosis (TB). Clin. Exp. Immunol. 2000, 122, 343-349. [CrossRef] [PubMed]

72. Ordway, D.G.; Costa, L.; Martins, M.; Silveira, H.; Amaral, L.; Arroz, M.J.; Ventura, F.A.; Dockrell, H.M. Increased Interleukin-4 Production by CD8 and $\gamma \delta 1 \mathrm{~T}$ cells in health-care workers is associated with the subsequent development of active tuberculosis. J. Infect. Dis. 2004, 190, 756-766. [CrossRef] [PubMed]

73. Hernandez-Pando, R.; Aguilar, D.; Hernandez, M.L.; Orozco, H.; Rook, G. Pulmonary tuberculosis in BALB/c mice with non-functional IL-4 genes: Changes in the inflammatory effects of TNF-alpha and in the regulation of fibrosis. Eur. J. Immunol. 2004, 34, 174-183. [CrossRef]

74. Fourman, L.T.; Saylor, C.F.; Cheru, L.; Fitch, K.; Looby, S.; Keller, K.; Robinson, J.A.; Hoffmann, U.; Lu, M.T.; Burdo, T.; et al. Anti-Inflammatory Interleukin 10 Inversely Relates to Coronary Atherosclerosis in Persons with Human Immunodeficiency Virus. J. Infect. Dis. 2020, 221, 510-515. [CrossRef] [PubMed]

75. Chang, J.; Naif, H.M.; Li, S.; Jozwiak, R.; Ho-Shon, M.; Cunningham, A.L. The inhibition of HIV replication in monocytes by interleukin 10 is linked to inhibition of cell differentiation. AIDS Res. Hum. Retrovir. 1996, 12, 1227-1235. [CrossRef]

76. Montaner, L.J.; Gordon, S. TH2 downregulation of macrophage HIV-1 replication. Science 1995, 267, 538-539. [CrossRef] [PubMed]

77. Arias, J.F.; Nishihara, R.; Bala, M.; Ikuta, K. High systemic levels of interleukin-10, interleukin-22 and C-reactive protein in Indian patients are associated with low in vitro replication of HIV-1 subtype C viruses. Retrovirology 2010, 7, 15. [CrossRef]

78. Lama, J.; Planelles, V. Host factors influencing susceptibility to HIV infection and AIDS progression. Retrovirology 2007, 4, 52. [CrossRef] [PubMed]

79. Ancuta, P.; Bakri, Y.; Chomont, N.; Hocini, H.; Gabuzda, D.; Haeffner-Cavaillon, N. Opposite Effects of IL-10 on the Ability of Dendritic Cells and Macrophages to Replicate Primary CXCR4-Dependent HIV-1 Strains. J. Immunol. 2001, 166, $4244-4253$. [CrossRef] [PubMed]

80. Sozzani, S.; Ghezzi, S.; Iannolo, G.; Luini, W.; Borsatti, A.; Polentarutti, N.; Sica, A.; Locati, M.; Mackay, C.; Wells, T.N.; et al. Interleukin 10 increases CCR5 expression and HIV infection in human monocytes. J. Exp. Med. 1998, 187, 439-444. [CrossRef] [PubMed]

81. Said, E.A.; Dupuy, F.P.; Trautmann, L.; Zhang, Y.; Shi, Y.; El-Far, M.; Hill, B.J.; Noto, A.; Ancuta, P.; Peretz, Y.; et al. Programmed death-1-induced interleukin-10 production by monocytes impairs CD4+ T cell activation during HIV infection. Nat. Med. 2010, 16, 452-459. [CrossRef]

82. Day, C.L.; Kaufmann, D.E.; Kiepiela, P.; Brown, J.A.; Moodley, E.S.; Reddy, S.; Mackey, E.W.; Miller, J.D.; Leslie, A.J.; DePierres, C.; et al. PD-1 expression on HIV-specific T cells is associated with T-cell exhaustion and disease progression. Nature 2006, 443, 350-354. [CrossRef]

83. Taga, K.; Cherney, B.; Tosato, G. IL-10 inhibits apoptotic cell death in human T cells starved of IL-2. Int. Immunol. 1993, 5, 1599-1608. [CrossRef] [PubMed]

84. Beamer, G.L.; Flaherty, D.K.; Assogba, B.D.; Stromberg, P.; Gonzalez-Juarerro, M.; de Waal Malefyt, R.; Vesosky, B.; Turner, J. Interleukin-10 promotes Mycobacterium tuberculosis disease progression in CBA/J mice. J. Immunol. 2008, 181, 5545-5550. [CrossRef] [PubMed]

85. Turner, J.; Gonzalez-Juarrero, M.; Ellis, D.L.; Basaraba, R.J.; Kipnis, A.; Orme, I.M.; Cooper, A.M. In Vivo IL-10 Production Reactivates Chronic Pulmonary Tuberculosis in C57BL/6 Mice. J. Immunol. 2003, 169, 6343-6351. [CrossRef] [PubMed]

86. Fenwick, C.; Joo, V.; Jacquier, P.; Noto, A.; Banga, R.; Perreau, M.; Pantaleo, G. T-cell exhaustion in HIV infection. Immunol. Rev. 2019, 292, 149-163. [CrossRef] [PubMed] 
87. Jayaraman, P.; Jacques, M.K.; Zhu, C.; Steblenko, K.M.; Stowell, B.L.; Madi, A.; Anderson, A.C.; Kuchroo, V.K.; Behar, S.M. TIM3 Mediates T Cell Exhaustion during Mycobacterium tuberculosis Infection. PLoS Pathog. 2016, 12, e1005490. [CrossRef] [PubMed]

88. Nosik, M.; Rymanova, I.; Lobach, O.; Sevostyanihin, S.; Kiseleva, I.; Adamovich, N.; Sobkin, A. Immune responses induced in individuals with dual infection Tuberculosis (TB) and HIV during antiretroviral and TB therapy. Int. J. Infect. Dis. 2016, 53, 85-86. [CrossRef]

89. Velazquez-Salinas, L.; Verdugo-Rodriguez, A.; Rodriguez, L.L.; Borca, M.V. The Role of Interleukin 6 During Viral Infections. Front. Microbiol. 2019, 10, 1057. [CrossRef] [PubMed]

90. Rose-John, S. IL-6 trans-signaling via the soluble IL-6 receptor: Importance for the pro-inflammatory activities of IL-6. Int. J. Biol. Sci. 2012, 8, 1237-1247. [CrossRef] [PubMed]

91. Neurath, M.F.; Finotto, S. IL-6 signaling in autoimmunity, chronic inflammation and inflammation-associated cancer. Cytokine Growth Factor Rev. 2011, 22, 83-89. [CrossRef]

92. Zhang, C.; Zhang, X.; Chen, X.H. Inhibition of the interleukin-6 signaling pathway: A strategy to induce immune tolerance. Clin. Rev. Allergy Immunol. 2014, 47, 163-173. [CrossRef]

93. Kilareski, E.M.; Shah, S.; Nonnemacher, M.R.; Wigdahl, B. Regulation of HIV-1 transcription in cells of the monocyte-macrophage lineage. Retrovirology 2009, 23, 118. [CrossRef]

94. Tanaka, T.; Kishimoto, T. The biology and medical implications of interleukin-6. Cancer Immunol. Res. 2014, 2, 288-294. [CrossRef] [PubMed]

95. Borges, Á.H.; O'Connor, J.L.; Phillips, A.N.; Rönsholt, F.F.; Pett, S.; Vjecha, M.J.; French, M.A.; Lundgren, J.D. Factors Associated with Plasma IL-6 Levels During HIV Infection. J. Infect. Dis. 2015, 212, 585-595. [CrossRef] [PubMed]

96. Wang, R.J.; Moore, J.; Moisi, D.; Chang, E.G.; Byanyima, P.; Kaswabuli, S.; Musisi, E.; Sanyu, I.; Sessolo, A.; Lalitha, R.; et al. HIV infection is associated with elevated biomarkers of immune activation in Ugandan adults with pneumonia. PLoS ONE 2019, 14, e0216680. [CrossRef]

97. Trovato, M.; Ruggeri, R.M.; Sciacchitano, S.; Vicchio, T.M.; Picerno, I.; Pellicanò, G.; Valenti, A.; Visalli, G. Serum interleukin-6 levels are increased in HIV-infected patients that develop autoimmune disease during long-term follow-up. Immunobiology 2018, 223, 264-268. [CrossRef] [PubMed]

98. Mugwe, J.N.; Gicheru, M.M.; Mwatha, J. Plasma Cytokine Profiles as Predictive Biomarkers of HIV and Aids Progression among HIV Patients Attending Nakuru Provincial General Hospital, Kenya. Am. J. Med. Biol. Res. 2016, 4, 20-25. [CrossRef]

99. Chandrashekara, S.; Anupama, K.R.; Sambarey, A.; Chandra, N. High IL-6 and low IL-15 levels mark the presence of TB infection: A preliminary study. Cytokine 2016, 81, 57-62. [CrossRef] [PubMed]

100. Haissman, J.; Vestergaard, L.S.; Sembuche, S.; Erikstrup, C.; Lemnge, M.; Gerstoft, J.; Ullum, H. Plasma cytokine levels in Tanzanian HIV-infected Adults and the Effect of Antiretroviral Treatment. JAIDS 2009, 52, 493-497. [CrossRef]

101. Dutta, R.K.; Kathania, M.; Raje, M.; Majumdar, S. IL-6 inhibits IFN-gamma induced autophagy in Mycobacterium tuberculosis H37Rv infected macrophages. Int. J. Biochem. Cell Biol. 2012, 44, 942-954. [CrossRef]

102. Poli, G.; Bressler, P.; Kinter, A.; Duh, E.; Timmer, W.C.; Rabson, A.; Justement, J.S.; Stanley, S.; Fauci, A.S. Interleukin 6 induces human immunodeficiency virus expression in infected monocytic cells alone and in synergy with tumor necrosis factor alpha by transcriptional and post-transcriptional mechanisms. J. Exp. Med. 1990, 172, 151-158. [CrossRef] [PubMed]

103. Wang, Q.; Su, L. Vpr Enhances HIV-1 Env Processing and Virion Infectivity in Macrophages by Modulating TET2-Dependent IFITM3 Expression. mBio 2019, 10, e01344-19. [CrossRef] [PubMed]

104. Lee, E.S.; Zhou, H.; Henderson, A.J. Endothelial cells enhance human immunodeficiency virus type 1 replication in macrophages through a C/EBP-dependent mechanism. J. Virol. 2001, 75, 9703-9712. [CrossRef]

105. Zhang, H.; Cao, X.; Xin, H.; Liu, J.; Pan, S.; Guan, L.; Shen, F.; Liu, Z.; Wang, D.; Guan, X.; et al. Serum level of IL-1ra was associated with the treatment of latent tuberculosis infection in a Chinese population. BMC Infect. Dis. 2020, 20, 330. [CrossRef]

106. Hoel, H.; Ueland, T.; Knudsen, A.; Kjær, A.; Michelsen, A.E.; Sagen, E.L.; Halvorsen, B.; Yndestad, A.; Nielsen, S.D.; Aukrust, P.; et al. Soluble Markers of Interleukin 1 Activation as Predictors of First-Time Myocardial Infarction in HIV-Infected Individuals. J. Infect. Dis. 2020, 221, 506-509. [CrossRef] [PubMed]

107. Dinarello, C.A. Interleukin-1 in the pathogenesis and treatment of inflammatory diseases. Blood 2011, 117, 3720-3732. [CrossRef]

108. Sudbury, E.L.; Otero, L.; Tebruegge, M.; Messina, N.L.; Seas, C.; Montes, M.; Rìos, J.; Germano, S.; Gardiner, K.; Clifford, V.; et al. Mycobacterium tuberculosis-specific cytokine biomarkers for the diagnosis of childhood TB in a TB-endemic setting. J. Clin. Tuberc. Other Mycobact. Dis. 2019, 16, 100102. [CrossRef]

109. Lin, P.L.; Flynn, J.L. Understanding latent tuberculosis: A moving target. J. Immunol. 2010, 185, 15-22. [CrossRef]

110. Ruth, J.H.; Bienkowski, M.; Warmington, K.S.; Lincoln, P.M.; Kunkel, S.L.; Chensue, S.W. IL-1 receptor antagonist (IL-1ra) expression, function, and cytokine-mediated regulation during mycobacterial and schistosomal antigen-elicited granuloma formation. J. Immunol. 1996, 156, 2503-2509.

111. Zavala, F.; Rimaniol, A.C.; Boussin, F.; Dormont, D.; Bach, J.F.; Descamps-Latscha, B. HIV predominantly induces IL-1 receptor antagonist over IL-1 synthesis in human primary monocytes. J. Immunol. 1995, 55, 2784-2793.

112. Granowitz, E.V.; Saget, B.M.; Wang, M.Z.; Dinarello, C.A.; Skolnik, P.R.; Fauci, A.S. Interleukin 1 Induces HIV-1 Expression in Chronically Infected U1 Cells: Blockade by Interleukin 1 Receptor Antagonist and Tumor Necrosis Factor Binding Protein Type 1. Mol. Med. 1995, 1, 667-677. [CrossRef] [PubMed] 
113. Vignesh, R.; Swathirajan, C.R.; Solomon, S.S.; Shankar, E.M.; Murugavel, K.G. Risk factors and frequency of tuberculosisassociated immune reconstitution inflammatory syndrome among HIV/Tuberculosis co-infected patients in Southern India. Indian J. Med. Microbiol. 2017, 35, 279-281. [CrossRef] [PubMed]

114. Gopal, R.; Rapaka, R.R.; Kolls, J.K. Immune reconstitution inflammatory syndrome associated with pulmonary pathogens. Eur. Respir. Rev. 2017, 26, 160042. [CrossRef] [PubMed]

115. Lai, R.P.; Meintjes, G.; Wilkinson, R.J. HIV-1 tuberculosis-associated immune reconstitution inflammatory syndrome. Semin. Immunopathol. 2016, 38, 185-198. [CrossRef]

116. Müller, M.; Wandel, S.; Colebunders, R.; Attia, S.; Furrer, H.; Egger, M. IeDEA Southern and Central Africa. Immune reconstitution inflammatory syndrome in patients starting antiretroviral therapy for HIV infection: A systematic review and meta-analysis. Lancet Infect. Dis. 2010, 10, 251-261. [CrossRef]

117. Murdoch, D.M.; Venter, W.D.; Van Rie, A.; Feldman, C. Immune reconstitution inflammatory syndrome (IRIS): Review of common infectious manifestations and treatment options. AIDS Res. Ther. 2007, 4, 9. [CrossRef]

118. Battegay, M.; Nüesch, R.; Hirschel, B.; Kaufmann, G.R. Immunological recovery and antiretroviral therapy in HIV-1 infection. Lancet Infect. Dis. 2006, 6, 280-287. [CrossRef]

119. Breton, G.; Duval, X.; Estellat, C.; Poaletti, X.; Bonnet, D.; Mvondo Mvondo, D.; Longuet, P.; Leport, C.; Vildé, J.-L. Determinants of immune reconstitution inflammatory syndrome in HIV type 1-infected patients with tuberculosis after initiation of antiretroviral therapy. Clin. Infect. Dis. 2004, 39, 1709-1712. [CrossRef]

120. Navas, E.; Martín-Dávila, P.; Moreno, L.; Pintado, V.; Casado, J.L.; Fortún, J.; Pérez-Elías, M.J.; Gomez-Mampaso, E.; Moreno, S. Paradoxical reactions of tuberculosis in patients with the acquired immunodeficiency syndrome who are treated with highly active antiretroviral therapy. Arch. Intern. Med. 2002, 162, 97-99. [CrossRef]

121. Narendran, G.; Andrade, B.B.; Porter, B.O.; Chandrasekhar, C.; Venkatesan, P.; Menon, P.A.; Subramanian, S.; Anbalagan, S.; Bhavani, K.P.; Sekar, S.; et al. Paradoxical tuberculosis immune reconstitution inflammatory syndrome (TB-IRIS) in HIV patients with culture confirmed pulmonary tuberculosis in India and the potential role of IL-6 in prediction. PLoS ONE 2013, 8, e63541. [CrossRef]

122. Karmakar, S.; Sharma, S.K.; Vashishtha, R.; Sharma, A.; Ranjan, S.; Gupta, D.; Sreenivas, V.; Sinha, S.; Biswas, A.; Gulati, V. Clinical characteristics of tuberculosis-associated immune reconstitution inflammatory syndrome in North Indian population of HIV / AIDS patients receiving HAART. Clin. Dev. Immunol. 2011, 2011, 239021. [CrossRef]

123. Michailidis, C.; Pozniak, A.L.; Mandalia, S.; Basnayake, S.; Nelson, M.R.; Gazzard, B.G. Clinical characteristics of IRIS syndrome in patients with HIV and tuberculosis. Antivir. Ther. 2005, 10, 417-422. [PubMed]

124. Olalla, J.; Pulido, F.; Rubio, R.; Costa, M.A.; Monsalvo, R.; Palenque, E.; Costa, J.R.; Del, P.A. Paradoxical responses in a cohort of HIV-1-infected patients with mycobacterial disease. Int. J. Tuberc. Lung Dis. 2002, 6, 71-75.

125. Wendel, K.A.; Alwood, K.S.; Gachuhi, R.; Chaisson, R.E.; Bishai, W.R.; Sterling, T.R. Paradoxical Worsening of Tuberculosis in HIV-Infected Persons. Chest 2001, 120, 193-197. [CrossRef]

126. Luetkemeyer, A.F.; Kendall, M.A.; Nyirenda, M.; Wu, X.; Ive, P.; Benson, C.A.; Andersen, J.W.; Swindells, S.; Sanne, I.M.; Havlir, D.V.; et al. Adult AIDS Clinical Trials Group A5221 Study Team. Tuberculosis immune reconstitution inflammatory syndrome in A5221 STRIDE: Timing, severity, and implications for HIV-TB programs. J. Acquir. Immune Defic. Syndr. 2014, 65, 423-428. [CrossRef]

127. Laureillard, D.; Marcy, O.; Madec, Y.; Chea, S.; Chan, S.; Borand, L.; Fernandez, M.; Prak, N.; Kim, C.; Dim, B.; et al. CAMELIA (ANRS 1295-CIPRA KH001) Study Team. Paradoxical tuberculosis-associated immune reconstitution inflammatory syndrome after early initiation of antiretroviral therapy in a randomized clinical trial. AIDS 2013, 27, 2577-2586. [CrossRef]

128. Naidoo, K.; Yende-Zuma, N.; Padayatchi, N.; Naidoo, K.; Jithoo, N.; Nair, G.; Bamber, S.; Gengiah, S.; El-Sadr, W.M.; Friedland, G.; et al. The immune reconstitution inflammatory syndrome after antiretroviral therapy initiation in patients with tuberculosis: Findings from the SAPiT trial. Ann. Intern. Med. 2012, 157, 313-324. [CrossRef]

129. Manosuthi, W.; Mankatitham, W.; Lueangniyomkul, A.; Thongyen, S.; Likanonsakul, S.; Suwanvattana, P.; Thawornwan, U.; Suntisuklappon, B.; Nilkamhang, S.; Sungkanuparph, S.; et al. Time to initiate antiretroviral therapy between 4 weeks and 12 weeks of tuberculosis treatment in HIV-infected patients: Results from the TIME study. J. Acquir. Immune Defic. Syndr. 2012, 60, 377-383. [CrossRef] [PubMed]

130. Bana, T.M.; Lesosky, M.; Pepper, D.J.; van der Plas, H.; Schutz, C.; Goliath, R.; Morroni, C.; Mendelson, M.; Maartens, G.; Wilkinson, R.J.; et al. Prolonged tuberculosis-associated immune reconstitution inflammatory syndrome: Characteristics and risk factors. BMC Infect. Dis. 2016, 16, 518. [CrossRef]

131. Huyst, V.; Lynen, L.; Bottieau, E.; Zolfo, M.; Kestens, L.; Colebunders, R. Immune reconstitution inflammatory syndrome in an HIV / TB co-infected patient four years after starting antiretroviral therapy. Acta Clin. Belg. 2007, 62, 126-129. [CrossRef]

132. Burman, W.; Weis, S.; Vernon, A.; Khan, A.; Benator, D.; Jones, B.; Silva, C.; King, B.; LaHart, C.; Mangura, B.; et al. Frequency, severity and duration of immune reconstitution events in HIV-related tuberculosis. Int. J. Tuberc. Lung Dis. 2007, 11, 1282-1289. [PubMed]

133. Xue, M.; Xie, R.; Pang, Y.; Yan, S.; Du, Y.; Guan, C.; Chen, B. Prevalence and risk factors of paradoxical tuberculosis associated immune reconstitution inflammatory syndrome among HIV-infected patients in Beijing, China. BMC Infect. Dis. 2020, $20,554$. [CrossRef] [PubMed] 
134. Hoyo-Ulloa, I.; Belaunzarán-Zamudio, P.F.; Crabtree-Ramirez, B.; Galindo-Fraga, A.; Pérez-Aguinaga, M.E.; Sierra-Madero, J.G. Impact of the immune reconstitution inflammatory syndrome (IRIS) on mortality and morbidity in HIV-infected patients in Mexico. IJID 2011, 15, e408-e414. [CrossRef]

135. Castelnuovo, B.; Manabe, Y.C.; Kiragga, A.; Kamya, M.; Easterbrook, P.; Kambugu, A. Cause-Specific Mortality and the Contribution of Immune Reconstitution Inflammatory Syndrome in the First 3 Years after Antiretroviral Therapy Initiation in an Urban African Cohort. Clin. Infect. Dis. 2009, 49, 965-972. [CrossRef] [PubMed]

136. Namale, P.E.; Abdullahi, L.H.; Fine, S.; Kamkuemah, M.; Wilkinson, R.J.; Meintjes, G. Paradoxical TB-IRIS in HIV-infected adults: A systematic review and meta-analysis. Future Microbiol. 2015, 10, 1077-1099. [CrossRef]

137. Clinical Guidelines Program. New York State Department of Health (NYSDOH) AIDS Institute. Management of Immune Reconstitution Inflammatory Syndrome (IRIS). Reviewed and Updated: April 2021. Available online: https://www.hivguidelines. org/antiretroviral-therapy/iris (accessed on 30 May 2021).

138. WHO; HIV/AIDS. Universal Antiretroviral Therapy (ART) for All HIV-Infected TB Patients. 2021. Available online: https: / / www.who.int/hiv/topics/tb/art_hivpatients/en/ (accessed on 30 May 2021).

139. Amogne, W.; Aderaye, G.; Habtewold, A.; Yimer, G.; Makonnen, E.; Worku, A.; Sonnerborg, A.; Aklillu, E.; Lindquist, L. Efficacy and Safety of Antiretroviral Therapy Initiated One Week after Tuberculosis Therapy in Patients with CD4 Counts $<200$ Cells $/ \mu L$ : TB-HAART Study, a Randomized Clinical Trial. PLoS ONE 2015, 10, e0122587. [CrossRef] [PubMed]

140. Sivro, A.; McKinnon, L.R.; Yende-Zuma, N.; Gengiah, S.; Samsunder, N.; Karim, S.S.A.; Naidoo, K. Plasma Cytokine Predictors of Tuberculosis Recurrence in Antiretroviral-Treated Human Immunodeficiency Virus-infected Individuals from Durban, South Africa. Clin. Infect. Dis. 2017, 65, 819-826. [CrossRef] [PubMed]

141. Herder, C.; de las Heras Gala, T.; Carstensen-Kirberg, M.; Huth, C.; Zierer, A.; Wahl, S.; Sudduth-Klinger, J.; Kuulasmaa, K.; Peretz, D.; Ligthart, S.; et al. Circulating Levels of Interleukin 1-Receptor Antagonist and Risk of Cardiovascular Disease. Arterioscler. Thromb. Vasc. Biol. 2017, 37, 1222-1227. [CrossRef] [PubMed]

142. Sindhu, S.; Toma, E.; Cordeiro, P.; Ahmad, R.; Morisset, R.; Menezes, J. Relationship of in vivo and ex vivo levels of TH1 and TH2 cytokines with viremia in HAART patients with and without opportunistic infections. J. Med. Virol. 2006, 78, 431-439. [CrossRef] 